\title{
Evidence for mantle heterogeneities in the westernmost Mediterranean from a statistical approach to volcanic petrology
}

\author{
Massimiliano Melchiorre ${ }^{\mathrm{a}, *}$, Jaume Vergés ${ }^{\mathrm{a}}$, Manel Fernàndez ${ }^{\mathrm{a}}$, Massimo Coltorti ${ }^{\mathrm{b}}$, \\ Montserrat Torne ${ }^{\mathrm{a}}$, Emilio Casciello ${ }^{\mathrm{a}}$ \\ a Group of Dynamics of the Lithosphere, Institute of Earth Sciences Jaume Almera ICTJA - CSIC, Lluís Solé i Sabarís s/n, 08028, Barcelona, Spain \\ b Department of Physics and Earth Sciences, Ferrara University, via Saragat 1, 44123 Ferrara, Italy
}

\section{A R T I C L E I N F O}

\section{Article history:}

Received 30 March 2016

Accepted 15 November 2016

Available online 27 November 2016

\section{Keywords:}

Factor analysis

Major and trace elements

Isotopic ratios

Geodynamic evolution

Orogenic and anorogenic volcanism

\begin{abstract}
A B S T R A C T
The geological evolution of the westernmost Mediterranean region is characterised by widespread volcanic activity, with subduction (orogenic) or intraplate (anorogenic) geochemical imprints. Major, trace elements and isotopic ratios of 283 orogenic and 310 anorogenic volcanic samples from the western and central Mediterranean areas were merged in a single database that was processed using a statistical approach. Factor analysis, performed using the Principal Component Analysis (PCA) method, reduced the original 36 geochemical parameters that were expressed as oxides, elements or isotopic ratios to seven factors that account for $\sim 84 \%$ of the variance. Combining these factors in binary diagrams clearly separates the anorogenic and orogenic fields. Anorogenic samples usually fall into a narrow compositional range, while orogenic rocks are characterised by greater variability and by alignment along different trends. These different trends are a result of large heterogeneities of the lithospheric mantle beneath the Mediterranean area because of extensive recycling of geochemically different lithologies, at least since Palaeozoic times. The results support the requirement for different mantle reservoirs in the origin of the Mediterranean volcanism. We find that the double subduction polarity model, recently proposed for the westernmost Mediterranean area, is compatible with the volcanic petrology of the last $30 \mathrm{My}$.
\end{abstract}

(c) 2016 Elsevier B.V. All rights reserved.

\section{Introduction}

The central and western Mediterranean area encompasses the region between the Calabrian and Gibraltar arcs, including a series of Neogene marine sedimentary basins (e.g., Alboran, Valencia Trough, Algerian, Liguro-Provençal, and Tyrrhenian), the surrounding Alpine belts (e.g., Betics, Catalan Coastal Ranges, Alps, Apennines, Rif-TellAtlas), the Balearic Promontory, and the Corsica-Sardinia block. The whole region forms part of the western Africa-Eurasia plate boundary, where a far-field compressive stress regime was coeval with regional extension. It is the site of active and recent subduction processes, and is characterised by Neogene to Recent volcanic activity.

The central and western Mediterranean area has been widely investigated with the following aims: 1 ) to reconstruct the plate kinematics (e.g., Carminati et al., 2012; Casciello et al., 2015; Dewey et al., 1989; Rabinowitz and LaBrecque, 1979; Rosenbaum et al., 2002b; Turco et al., 2012; Van der Voo, 1993; Vergés and Fernàndez, 2012); 2) to emphasise the seismic images in order to propose snapshots of presentday lithospheric domains beneath Europe and the Mediterranean (e.g., Bezada et al., 2013; Chiarabba et al., 2014; Giacomuzzi et al.,

\footnotetext{
* Corresponding author.

E-mail address: mmelchiorre@ictja.csic.es (M. Melchiorre).
}

2012; Gutscher et al., 2002; Palomeras et al., 2014; Piromallo and Morelli, 2003; Spakman and Wortel, 2004; Thurner et al., 2014; Wortel et al., 2009); and 3) to describe the volcanic activity that affected several areas from Spain to northern Italy and from northern Africa to central Europe since the Oligocene (Beccaluva et al., 2004, 2013; Carminati et al., 2012; Coulon et al., 2002; El Azzouzi et al., 1999, 2014; Harangi et al., 2006; Lustrino and Wilson, 2007; Lustrino et al., 2011). The volcanic activity in the central and western Mediterranean region can be broadly divided into two main types (Fig. 1) on the basis of their tectonic and geochemical features (see Lustrino and Wilson, 2007 and Lustrino et al., 2011 for reviews). Orogenic or subduction-related volcanism usually refers to volcanic rocks generated by continent-continent collision or are associated with subduction of oceanic lithosphere (e.g., Carminati and Doglioni, 2004). It comprises arc tholeiitic, calc-alkaline, high potassium (HK) calc-alkaline, shoshonitic and ultrapotassic products. Anorogenic or intraplate volcanism is associated with a post-collisional environment and includes alkaline rocks with sodic affinity. Combining this information, several and sometimes competing geodynamic models have been put forward to explain the Tertiary tectonic evolution of the western Mediterranean area (Doblas et al., 2007).

Tomographic models have resulted in a consensus on the extent, shape and dip of the present-day subducting slabs in the region. 


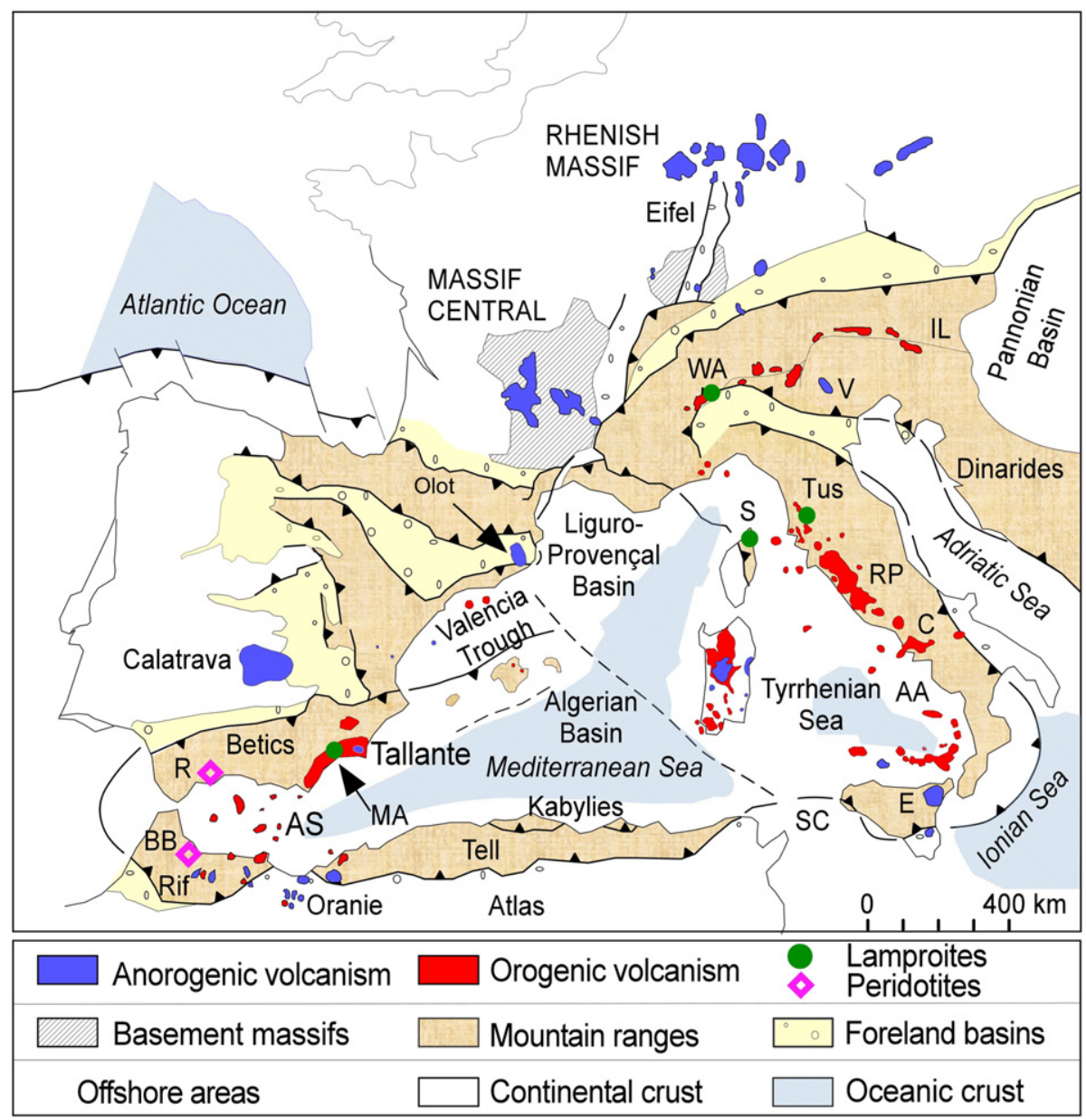

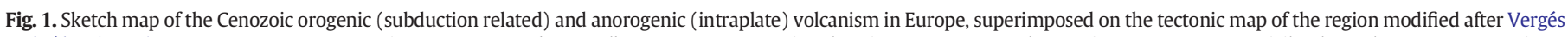

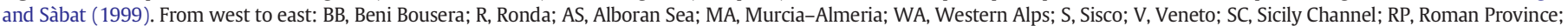
C, Campania; AA, Aeolian Arc; E, Etna; IL, Insubric Line.

However, discrepancies arise concerning the initiation of subduction relative to the extent of the subduction front, its orientation and dip. Some authors have proposed an initial N-NW dipping subduction front that extended from the Alps to the present-day Gibraltar Arc (e.g., Carminati et al., 2012; Faccenna et al., 2004; Schettino and Turco, 2006). Other authors proposed restrictions on the initial N-NW dipping subduction zone from the Alps to the southwest termination of the present-day Balearic Promontory (e.g., Rosenbaum and Lister, 2004; Spakman and Wortel, 2004; van Hinsbergen et al., 2014). A third model proposed a lateral change in the initial subduction polarity from S-SE along the north Moroccan margin to N-NW along the Balearic Promontory to the Alps (Casciello et al., 2015; Vergés and Fernàndez, 2012).

The incorporation of volcanism into these models is uneven. Duggen et al. $(2004,2005)$ explained the geochemical features of westernmost Mediterranean volcanism as a result of delamination in a context of a westward roll-back phase. Booth-Rea et al. (2007) used the volcanism to support a model in which E-dipping subduction beneath the Alboran and Algero-Balearic basins was active until the late Miocene, when it stopped, probably because of the complete consumption of the oceanic crust. The Si-K-rich volcanism is interpreted as a result of anatexis because of the direct contact of the asthenosphere with the base of the crust, driven by delamination of the lithospheric mantle (Bird, 1979). Wilson and Bianchini (1999) provided clues for the origin of the most primitive mafic igneous rocks that can be considered as the best indicator for the initial geodynamic setting. Harangi et al. (2006) dealt with the subduction-related volcanic rocks and their relation with competing geodynamic models proposed for the evolution of the central and western Mediterranean. Finally, Lustrino and different co-workers (Lustrino, 2011; Lustrino and Wilson, 2007; Lustrino et al., 2011) presented an overview of the two main geochemically different magma-types (anorogenic and orogenic), with an aim of providing a general model for the petrogenesis of the intraplate affinity suite and a possible relationship between tectonic evolution and geochemistry of the subduction-related rocks.

The huge amount of available information on the geochemistry of the volcanic products in the western and central Mediterranean area makes its incorporation into the proposed geodynamic models difficult, mainly due to the extreme heterogeneity of the data. A way to manage large numbers of variables with no obvious relationships among them is to use a factor analysis technique. Although this technique is used widely in the social and life sciences and is becoming a common method in earth science, it is not yet used in volcanic geochemistry. In this paper, we present the results obtained by applying a factor analysis (using the principal component method) to a large database composed of Mediterranean orogenic (Lustrino et al., 2011) and anorogenic (Lustrino and Wilson, 2007) volcanic rocks. Factor analysis is here used to remove redundant variables and to replace the entire geochemical data file by a smaller number of variables in order to support previous geochemical interpretations and to ascertain the utility of the method.

Our main aims are: 1 ) to verify whether a factor analysis technique can be applied to geochemical issues; 2) to highlight the differences in geochemical composition of the intraplate affinity and subduction- 
related volcanic rocks of the western and central Mediterranean, and the evolution of these differences over time and 3) to constrain the origin of the mantle heterogeneities which are present in the source of the volcanism. Furthermore, we analyse the compatibility between the geochemical signature of the volcanism in the westernmost Mediterranean and a recently proposed geodynamic model based on a lateral change of subduction polarity (Casciello et al., 2015; Vergés and Fernàndez, 2012).

\section{Cenozoic tectonic evolution of the Central and Western Mediterranean}

The central and western Mediterranean region has undergone a complex geodynamic evolution since the early Cretaceous. This complex history is recorded in the Alpine orogeny (Dal Piaz et al., 2003), in the numerous areas where magmatism and orogenesis occurred (Araña et al., 1983; Beccaluva et al., 2011, 2013; Cebriá and López-Ruiz, 1995; Harangi et al., 2006; Lustrino and Wilson, 2007; Lustrino et al., 2011), and in the formation of several back-arc basins that opened because of roll-back of lithospheric slabs with various retreat directions (e.g., Carminati et al., 2012). These basins (Fig. 1) are the Liguro-Provençal and the Tyrrhenian basins (Doglioni et al., 2004; Faccenna et al., 1997; Van der Voo, 1993), the Valencia Trough and the Algerian Basin (Ayala et al., 2003; Carballo et al., 2015; Martí et al., 1992; Roca et al., 2004; Torne, 1996; Vergés and Sàbat, 1999), and the Alboran Basin (Comas et al., 1992, 1999; Frizon de Lamotte et al., 2000; García-Dueñas et al., 1992; Soto et al., 2008; Torne et al., 2000). The overall tectonic framework in which this evolution occurred is characterised by convergence between the African and Eurasian plates caused by the opening of the southern Atlantic Ocean. From Early Cretaceous times on, Africa moved slowly toward Eurasia with a NE-directed counter-clockwise rotation (Dewey et al., 1989; Mazzoli and Helman, 1994; Rosenbaum et al., 2002a), shifting to a NNW direction at about $40 \mathrm{Ma}$ (Rosenbaum et al., 2002a, 2002b), and finally to a N-S direction (Devoti et al., 2008).

It is widely accepted that the evolution of the central Mediterranean area is linked to the roll-back of Tethyan oceanic lithosphere that had remained landlocked since the Oligocene. However, despite the consensus among mantle tomography models that image a subducted and partly torn slab beneath the Betic-Rif orogen (e.g., Bonnin et al., 2014; Díaz et al., 2012; Fichtner and Villaseñor, 2015; Miller et al., 2013; Spakman and Wortel, 2004; Thurner et al., 2014), the debate focuses on how to trace the evolution of these subducted plates back to their initial configuration.

The earliest tectonic reconstructions considered that the central and western Mediterranean basins and surrounding chains resulted from extensional stresses that dismantled the western Alpine belt. This orogenic dismembering produced the radial dispersion of its high pressure-low temperature (HP-LT) 'collisional' metamorphic rocks to form the Calabria-Peloritani, Kabilyes and Alboran terranes (Alvarez and Shimabukuro, 2009; Alvarez et al., 1974; Boccaletti and Guazzone, 1974). As argued in Casciello et al. (2015), this initial interpretation had a strong influence on later reconstructions that, in the case of the westernmost Mediterranean area, can be grouped into three different hypotheses:

1) The original Alpine belt formed a continuous chain from the presentday Alps to the Gibraltar area and was related to NW-directed subduction, at least since the middle Eocene, incorporating the HP-LT metamorphic domains of the future Betic-Rif Internal Zone (Alboran Domain), the Kabylies blocks, and the Calabria-Peloritani units. Further retreat and slab roll-back towards the SE caused dispersal of the metamorphic units following a radial pattern. The CalabriaPeloritani units moved ESE together with the Sardinia-Corsica block during the opening of the Liguro-Provençal Basin, whereas the Kabylies shifted southwards during the opening of the Algerian Basin (e.g., Faccenna et al., 2004, 2014; Jolivet and Faccenna, 2000).
These authors introduced the concept of slab tears in the subducting lithosphere to allow for an independent WSW roll-back in the Gibraltar area, with respect to the overall S-directed roll-back of the Algerian slab. The main criticism of this model is that the formation of the Miocene NW-verging Betic orogen and the S- to E-dipping present-day subduction polarity are poorly explained.

2) A second model proposes that the initial N-NW dipping subduction zone extended from the Alps to the south of the present position of the Balearic Promontory (e.g., Lonergan and White, 1997; Rosenbaum and Lister, 2004; Spakman and Wortel, 2004; van Hinsbergen et al., 2014). Similar to the previous model, this orogenic belt was composed of HP-LT metamorphic units that dismembered radially, because of slab roll-back. The main difference with the previous model is that the segment of the subduction front, associated with the present Balearic block, underwent a clockwise rotation of $\sim 180^{\circ}$ which was accommodated by lithospheric tearing along the North African margin. This allowed for over $500 \mathrm{~km}$ of westward movement of the Alboran domain and the E-W opening of the Algerian basin (van Hinsbergen et al., 2014).

3) The latest interpretation has been proposed by Vergés and Fernàndez (2012). Based on the position of high-grade metamorphic rocks with respect to subduction polarity and several other geological and geophysical constraints, these authors suggested that the Betic-Rif Arc originated from the Oligocene-Miocene northwestward and westward roll-back of the southeast-dipping subduction of Ligurian Tethys lithosphere below Africa. In this view, the Late Oligocene-Miocene evolution of the central and western Mediterranean is linked to two opposite dipping subductions: a northwest-dipping, southeast-retreating subduction related to the migration of the Kabylies units, and a southeast-dipping, northwest-retreating subduction related to the formation of the Betic-Rif orogen.

\section{Geochemical data and factor analysis}

Two large databases in the literature include much of the volcanic activity that has occurred in the Mediterranean area from the Oligocene to the present-day (Fig. 1). A compilation of the orogenic-related rocks has been published by Harangi et al. (2006) and more recently by Lustrino et al. (2011), while the geochemical data of the anorogenic rocks were gathered by Lustrino and Wilson (2007), and further updated by Lustrino (2011). For comparison, we also considered the Canary Islands dataset that, as expected, shows a monotonous and unambiguous intraplate signature from Oligocene to Recent.

The main limitation of such large datasets is visualisation of the wealth of information they contain. In geochemistry, binary or ternary diagrams are used to identify significant variation in chemistry, combining major, trace elements and isotopic ratios. However, even if elemental ratios are considered, it is highly unlikely to observe, at the same time, variations of more than six elements. Hence, typically, several diagrams are used to display the chemical data, which often distract the attention of the researcher from the final goal of unravelling the geochemical evolution of a suite of rocks, and to insert them in a coherent geodynamic framework. In this respect, a statistical approach through factor analysis can help, as a powerful tool to combine more elements and allowing us to summarise geochemical variations in a few binary diagrams.

The orogenic volcanic dataset of Lustrino et al. (2011) is a compilation of $>7,000$ samples, while its anorogenic counterpart accounts for $\sim 7,800$ analyses (Lustrino, 2011). These databases have been merged and filtered by choosing those samples that are characterised by the most complete geochemical dataset in terms of:

a) Major elements, expressed as oxides of $\mathrm{Si}$, Ti, $\mathrm{Al}, \mathrm{Fe}, \mathrm{Mn}, \mathrm{Mg}, \mathrm{Ca}, \mathrm{Na}$, $\mathrm{K}, \mathrm{P}$.

b) Trace elements, including Large Ion Lithophile Elements (LILE) - Cs, $\mathrm{Rb}, \mathrm{Ba}, \mathrm{Sr}$ and $\mathrm{Pb}$; High Field Strength Elements (HFSE) - Th, U, Nb, 
Ta, Zr and Hf; and Rare Earth Elements (REE) - La, Ce, Pr, Nd, Sm, Eu, Gd, Tb, Dy, Ho, Er, Tm, Yb, Y and Lu.

c) Isotopic composition, mainly expressed by ${ }^{87} \mathrm{Sr} /{ }^{86} \mathrm{Sr},{ }^{143} \mathrm{Nd} /{ }^{144} \mathrm{Nd}$, ${ }^{206} \mathrm{~Pb} /{ }^{204} \mathrm{~Pb}{ }^{207} \mathrm{~Pb} /{ }^{204} \mathrm{~Pb},{ }^{208} \mathrm{~Pb} /{ }^{204} \mathrm{~Pb},{ }^{208} \mathrm{~Pb} /{ }^{206} \mathrm{~Pb}$ and ${ }^{207} \mathrm{~Pb} /{ }^{206} \mathrm{~Pb}$.

After filtering, a total of 283 orogenic and 310 anorogenic volcanic samples were selected (Fig. 2). This procedure led us to completely exclude samples from Algeria and Tunisia, and to select only three samples from Sardinia and one from Corsica (Sisco). We built a 593 x 43 matrix in which each row represents a sample and each column represents a variable (i.e., a geochemical element characterising the sample). This matrix was processed in order to obtain standardised values that are expressed as $Z_{i}=\left(x_{i}-x_{m}\right) / \sigma$, where $x_{i}$ is the non-standardised value of variable $x, x_{m}$ is the mean value of variable $x$, and $\sigma$ is the standard deviation of variable $x$. The standardisation procedure inflates variables whose variance is small, reduces the influence of variables whose variance is large, and removes the influence of different measurement units in the data by making them dimensionless.

Factor analysis is a multivariate statistical method used to represent a large number of variables in the original data by a substantially smaller number of factors. The term factor in geochemistry refers to controlling processes and factor analysis is ideally suited for an easy presentation of the essential information in a geochemical dataset (Reimann et al., 2002). The aim of statistical analysis is to reduce the dimensionality of the original space, thus allowing for a more comprehensible interpretation of a reduced number of dimensions which underlie the old dimensions (Rietveld and Van Hout, 1993).

For this purpose, the matrix has been processed using the Statistical Package for Social Sciences (SPSS) version 17, which allowed a first reduction of the number of variables to describe the 593 samples by reading the communality value (between 0 and 1 ). The communality of a variable is an automatically calculated parameter, based on the sum of the loadings of this variable on all of the extracted factors, which reflects the percentage of variance in a given variable that jointly encompasses all of the factors (interpreted as the reliability of the indicator). Those variables with communality $<0.6$ were considered meaningless and were disregarded. The matrix was reprocessed until all variables had communality $>0.6$, thus excluding $\mathrm{MnO}, \mathrm{Cs}, \mathrm{Ta}, \mathrm{Hf}, \mathrm{Gd}$, Er and ${ }^{207} \mathrm{~Pb} /{ }^{204} \mathrm{~Pb}$ isotopic ratio in the final factor analysis.

The starting point of factor analysis is a correlation matrix obtained by calculating the correlations between each pair of variables. Extraction of the factors is undertaken by calculating the eigenvalues of the correlation matrix. The number of positive eigenvalues determines the number of dimensions needed to describe the set of scores without losing information, and the number of extracted factors (Rietveld and Van Hout, 1993). Construction of the factor is based on a transformation matrix that is given by the eigenvectors of the eigenvalues (Rietveld and Van Hout, 1993). Once the factors have been extracted, the factor loadings are calculated by correlating the original variables and the newly obtained factors. The first factor accounts for the maximum part of the variance, the second factor accounts for the maximum part of the remaining variance, and so on. In our case, seven factors (F) were extracted that account for 84\% of the cumulative variance (F1 22.7\%; F2 18.6\%; F3 12.2\%; F4 11.8\%; F5 6.4\%; F6 6.4\%; F7 6.1\%) (Table 1).

The interpretation of the obtained factors can be problematic because the original variables have high loadings on the first factors as they account for most of the variance. To get around this problem, an orthogonal (Varimax) factor rotation is applied. Finally, each standardised variable score is multiplied by the corresponding standardised scoring coefficient, and the sum of these products results in the factor scores (Supplementary Figure). In our case, the number of orogenic and anorogenic samples must be similar in order to avoid the dominance of one over another in extracting the main factors.

The factor scores are plotted in binary diagrams (Supplementary Figure) in order to observe the variations affecting the samples in terms of controlling processes. Considering that the factors are combinations of all the variables used for the geochemical description and that each factor is standardised to a mean value of 0 and a variance of 1 , the intersection of the axes represents the mean of all the variables. For example, in the F2 vs. F1, diagram the intersection of the axes represents

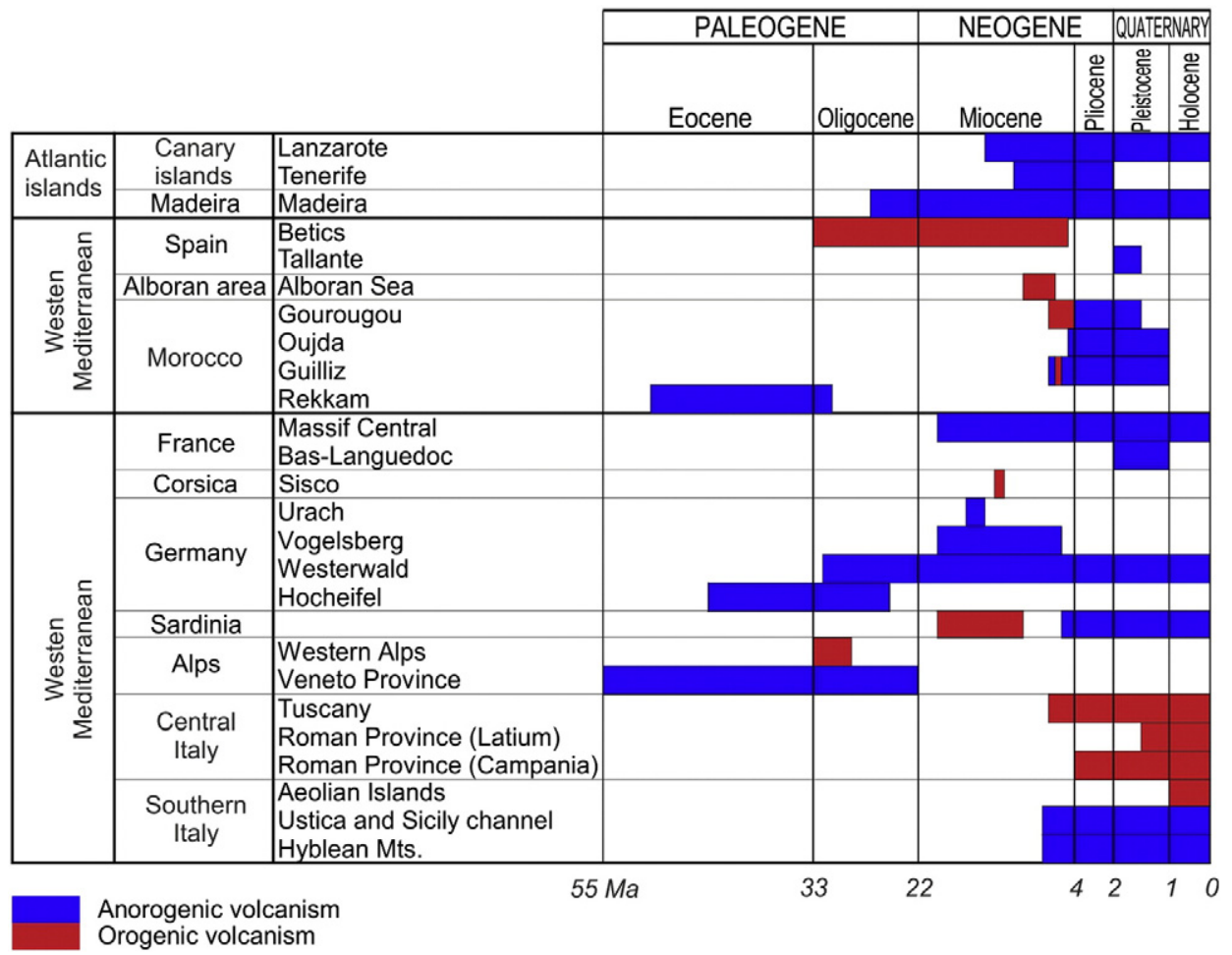

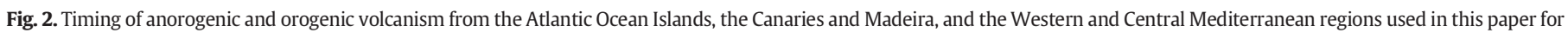
statistical purposes. For references refer to Fig. 4. 
Table 1

Initial Eigenvalues, extraction and rotation of the sums of the squared loadings from factor analysis.

\begin{tabular}{|c|c|c|c|c|c|c|c|c|c|}
\hline \multirow[b]{2}{*}{ Component } & \multicolumn{3}{|c|}{ Initial Eigenvalues } & \multicolumn{3}{|c|}{ Extraction Sums of Squared Loadings } & \multicolumn{3}{|c|}{ Rotation Sums of Squared Loadings } \\
\hline & Total & $\%$ of Variance & Cumulative \% & Total & $\%$ of Variance & Cumulative \% & Total & $\%$ of Variance & Cumulative $\%$ \\
\hline 1 & 11.318 & 31.438 & 31.438 & 11.318 & 31.438 & 31.438 & 8.183 & 22.732 & 22.732 \\
\hline 2 & 7.595 & 21.098 & 52.536 & 7.595 & 21.098 & 52.536 & 6.697 & 18.602 & 41.333 \\
\hline 3 & 3.990 & 11.084 & 63.620 & 3.990 & 11.084 & 63.620 & 4.410 & 12.249 & 53.582 \\
\hline 4 & 2.447 & 6.796 & 70.416 & 2.447 & 6.796 & 70.416 & 4.234 & 11.762 & 65.344 \\
\hline 5 & 2.125 & 5.902 & 76.318 & 2.125 & 5.902 & 76.318 & 2.302 & 6.394 & 71.738 \\
\hline 6 & 1.565 & 4.347 & 80.665 & 1.565 & 4.347 & 80.665 & 2.270 & 6.306 & 78.044 \\
\hline 7 & 1.265 & 3.513 & 84.178 & 1.265 & 3.513 & 84.178 & 2.208 & 6.134 & 84.178 \\
\hline
\end{tabular}

the point where the values of the variables, that are weighted by these two factors, coincide with their mean. Moving away from the axes intersection, the values of the variables will increase (positive side of the axes) or decrease (negative side of the axes) with respect to the mean.

\section{Outcomes of the factor analysis}

F1 is characterised by a positive correlation with $\mathrm{K}_{2} \mathrm{O},{ }^{87} \mathrm{Sr} /{ }^{86} \mathrm{Sr}, \mathrm{Rb}$, $\mathrm{Sm}$ and a group of highly mobile elements such as $\mathrm{U}$, Th and $\mathrm{Pb}$, and by a negative correlation with $\mathrm{Fe}_{2} \mathrm{O}_{3}, \mathrm{CaO}$ and ${ }^{143} \mathrm{Nd} /{ }^{144} \mathrm{Nd}$ (Table 2). F2 depends positively on $\mathrm{Sr}$ and $\mathrm{Ba}$, as well as on some Light REE (LREE; La, Ce and Nd), Medium REE (MREE; Eu, Dy) and Y. F3 shows a positive correlation with $\mathrm{TiO}_{2}, \mathrm{MgO}$ and $\mathrm{P}_{2} \mathrm{O}_{5}$ and a negative correlation with $\mathrm{SiO}_{2}$ and $\mathrm{Al}_{2} \mathrm{O}_{3}$. F4 depends positively on Heavy REE (HREE) and $\mathrm{Pr}$ (LREE), while F5 is dependent on $\mathrm{Na}_{2} \mathrm{O}, \mathrm{Zr}$ and $\mathrm{Nb}$. Statistically, Pr is correlated with F4, although most of the LREE are associated with F2.

Table 2

Rotated component matrix of the calculated seven factors. Bold represents the best correlation between geochemical elements and factors.

\begin{tabular}{|c|c|c|c|c|c|c|c|}
\hline & \multicolumn{7}{|c|}{ Factors } \\
\hline & 1 & 2 & 3 & 4 & 5 & 6 & 7 \\
\hline $\mathrm{SiO}_{2}$ & .540 & -.456 & -.563 & .023 & .054 & -.209 & -.169 \\
\hline $\mathrm{TiO}_{2}$ & -.547 & .037 & .614 & .068 & .330 & .132 & .190 \\
\hline $\mathrm{Al}_{2} \mathrm{O}_{3}$ & -.030 & -.172 & -.831 & .018 & .004 & .182 & -.004 \\
\hline $\mathrm{Fe}_{2} \mathrm{O}_{3}$ & -.715 & .053 & .552 & .056 & -.033 & .166 & .142 \\
\hline $\mathrm{MgO}$ & -.246 & .022 & .837 & -.115 & -.115 & .068 & .050 \\
\hline $\mathrm{CaO}$ & -.531 & .527 & .410 & -.013 & -.406 & .119 & .077 \\
\hline $\mathrm{Na}_{2} \mathrm{O}$ & -.346 & -.019 & -.494 & -.031 & .683 & -.086 & -.005 \\
\hline $\mathrm{K}_{2} \mathrm{O}$ & .829 & .111 & -.287 & .084 & .134 & .026 & .096 \\
\hline $\mathrm{P}_{2} \mathrm{O}_{5}$ & -.036 & .510 & .659 & .113 & .251 & .083 & .108 \\
\hline${ }^{87} \mathrm{Sr} /{ }^{86} \mathrm{Sr}$ & .919 & -.053 & -.014 & .038 & -.149 & .095 & -.123 \\
\hline${ }^{143} \mathrm{Nd} /{ }^{144} \mathrm{Nd}$ & -.825 & -.039 & .215 & -.017 & .285 & -.074 & .204 \\
\hline${ }^{206} \mathrm{~Pb} /{ }^{204} \mathrm{~Pb}$ & -.361 & .082 & .180 & -.031 & .138 & -.162 & .828 \\
\hline${ }^{208} \mathrm{~Pb} /{ }^{204} \mathrm{~Pb}$ & .020 & .121 & .037 & -.004 & .014 & -.122 & .915 \\
\hline${ }^{208} \mathrm{~Pb} /{ }^{206} \mathrm{~Pb}$ & .003 & .042 & .041 & -.073 & .000 & .974 & -.100 \\
\hline${ }^{207} \mathrm{~Pb} /{ }^{206} \mathrm{~Pb}$ & .016 & .034 & .030 & -.070 & -.006 & .969 & -.156 \\
\hline $\mathrm{Rb}$ & .888 & .071 & -.107 & .128 & .055 & .028 & .072 \\
\hline Sr & -.036 & .925 & .059 & .065 & -.136 & .021 & -.018 \\
\hline $\mathrm{Ba}$ & .515 & .658 & .170 & .029 & -.002 & .055 & -.136 \\
\hline $\mathrm{Y}$ & .051 & .623 & -.236 & .406 & .099 & -.085 & .296 \\
\hline $\mathrm{Zr}$ & .449 & .231 & .116 & .041 & .757 & .081 & .140 \\
\hline $\mathrm{Nb}$ & -.317 & .526 & .161 & .053 & .644 & -.027 & .135 \\
\hline La & .184 & .772 & .038 & .408 & .173 & -.012 & -.015 \\
\hline $\mathrm{Ce}$ & .387 & .843 & .083 & .173 & .158 & -.002 & .096 \\
\hline $\operatorname{Pr}$ & .394 & .529 & .204 & .625 & .016 & .017 & -.043 \\
\hline $\mathrm{Nd}$ & .543 & .643 & .233 & .175 & .151 & .051 & .103 \\
\hline $\mathrm{Sm}$ & .519 & .491 & .294 & .345 & .163 & .069 & .052 \\
\hline $\mathrm{Eu}$ & .180 & .647 & .443 & .371 & .232 & .195 & .105 \\
\hline $\mathrm{Tb}$ & .221 & .205 & .095 & .843 & -.026 & .050 & -.042 \\
\hline Dy & .098 & .705 & .026 & .366 & .185 & .003 & .353 \\
\hline Ho & -.059 & .218 & .028 & .885 & -.036 & -.048 & .053 \\
\hline $\mathrm{Tm}$ & .098 & .091 & -.097 & .933 & -.033 & -.115 & -.074 \\
\hline $\mathrm{Yb}$ & .112 & .450 & -.498 & .334 & .209 & -.204 & .358 \\
\hline Lu & .061 & .236 & -.402 & .666 & .246 & -.106 & .120 \\
\hline Th & .855 & .290 & .133 & .148 & .137 & -.065 & -.045 \\
\hline $\mathrm{Pb}$ & .793 & .294 & -.124 & .122 & -.029 & .047 & .018 \\
\hline U & .729 & .426 & .135 & .156 & .026 & -.168 & -.124 \\
\hline
\end{tabular}

Finally F6 and F7 depend positively on $\mathrm{Pb}$ isotopic ratios. F6 is correlated with ${ }^{208} \mathrm{~Pb} /{ }^{206} \mathrm{~Pb}$ and ${ }^{207} \mathrm{~Pb} /{ }^{206} \mathrm{~Pb}$, whereas F7 correlates to ${ }^{206} \mathrm{~Pb} /{ }^{204} \mathrm{~Pb}$ and ${ }^{208} \mathrm{~Pb} /{ }^{204} \mathrm{~Pb}$. By combining the seven factors in binary diagrams (Supplementary Figure), we observed that factors F1, F2, F3 and F5 explain the majority of the chemical variations. Fig. 3 shows the plots of the rotated component matrix expressed as binary diagrams of F2 vs. F1, F3 vs. F1 and F5 vs. F3. These plots help in understanding what variables influence the different factors more. On the other hand, in Figs. 4 and 5 we use the factor scores obtained for each sample in order to understand how the volcanic rocks in this study are related to the different factors (i.e., to the different original variable or chemical components).

On the whole, both orogenic and anorogenic samples show wide variations of all the factors (Fig. 4 and Supplementary Figure). Most localities show a wide compositional range, in terms of both F1 and F2 (Fig. 5A and B), except Sardinia and Corsica (Sisco) which have very few samples. Orogenic samples from Campania and the Aeolian Islands mostly straddle the zero axis intersection (Fig. 5A), indicating that their compositions are close to the mean values of all variables included in $\mathrm{F} 1$ and F2. No correlation is found between composition and age, except some recent Campanian volcanic products shifting towards higher F1 values that are characterised by an increase in $\mathrm{K}_{2} \mathrm{O}, \mathrm{Rb}, \mathrm{Sm}, \mathrm{U}$, Th and $\mathrm{Pb}$ contents, as well as radiogenic ${ }^{87} \mathrm{Sr} /{ }^{86} \mathrm{Sr}$. On the other hand, samples of the Roman Province, Western Alps and Tuscany, mostly plotting on the positive side of the $\mathrm{x}$-axis, show alignments along different trends (Fig. 5A). Note that Tuscany samples include some rocks from Capraia but not from Elba Island. Three features can be highlighted: 1) Roman Province volcanic products show a very wide compositional range in terms of both $\mathrm{F} 1$ and $\mathrm{F} 2$, thus being characterised by an increase of $\mathrm{K}_{2} \mathrm{O}, \mathrm{Rb}, \mathrm{Sm}, \mathrm{U}, \mathrm{Th}, \mathrm{Pb}$, and more radiogenic ${ }^{87} \mathrm{Sr} /{ }^{86} \mathrm{Sr}$, coupled with a decrease of $\mathrm{Fe}_{2} \mathrm{O}_{3}$ and $\mathrm{CaO}$, and less radiogenic ${ }^{143} \mathrm{Nd} /{ }^{144} \mathrm{Nd}$, as well as by enrichment in Sr, Ba, LREE, MREE and Y contents; 2) All samples from Tuscany plot on the negative side of the F2-axis, highlighting a lower content of Sr, Ba, LREE, MREE and Y with respect to the Roman Province volcanics. One of the Tuscany lamproites shows a lower LREE content than the Roman province samples. At the same time, Tuscany samples show an increase in elements related to F1, with the highest contents observed in lamproites. Western Alps samples plot between the Roman and Tuscan provinces trends; 3 ) There is a temporal correlation of the volcanic products of Tuscany, with the lamproites (4.1 Ma) associated with calc-alkaline, HK calc-alkaline and shoshonitic rocks $(0.88$ $1.35 \mathrm{Ma}$ ), being the first in the eruption sequence (Conticelli et al., 2004; Ferrara and Tonarini, 1985; and references therein).

In the westernmost Mediterranean (Fig. 5B), the orogenic samples of southern Spain, Morocco and Alboran Basin (Fig. 1) are mostly aligned along a unique trend that starts from slightly negative F1 and F2 values and evolves towards higher F1 and slightly lower F2 values. Lamproites of southern Spain clearly plot outside this trend, between -1 and + 1 F2 values, and are characterised by the highest $\mathrm{F} 1$ values, indicating highest $\mathrm{K}_{2} \mathrm{O}, \mathrm{Rb}, \mathrm{Sm}, \mathrm{U}$, Th and $\mathrm{Pb}$ contents and the highest ${ }^{87} \mathrm{Sr} /{ }^{86} \mathrm{Sr}$, coupled with the lowest $\mathrm{Fe}_{2} \mathrm{O}_{3}$ and $\mathrm{CaO}$ contents and the lowest ${ }^{143} \mathrm{Nd} /{ }^{144} \mathrm{Nd}$. In contrast to the Tuscany rocks, the Spanish volcanic rocks (lamproites, calc-alkaline, HK calc-alkaline and shoshonitic rocks) are characterised by an opposite time sequence (Conticelli et al., 2009a). Lamproitic 

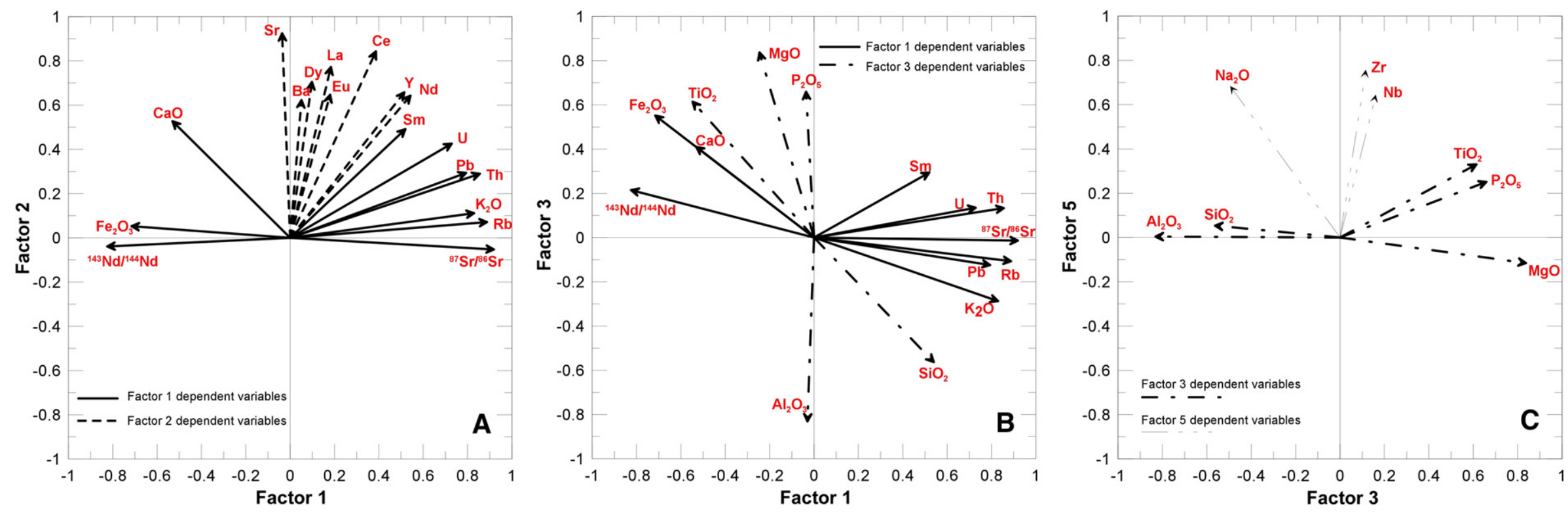

Fig. 3. Representative binary plots of the rotated component matrix in terms of F2 vs. F1 (A), F3 vs. F1 (B) and F5 vs. F3 (C) diagrams. See text for a comprehensive explanation. 

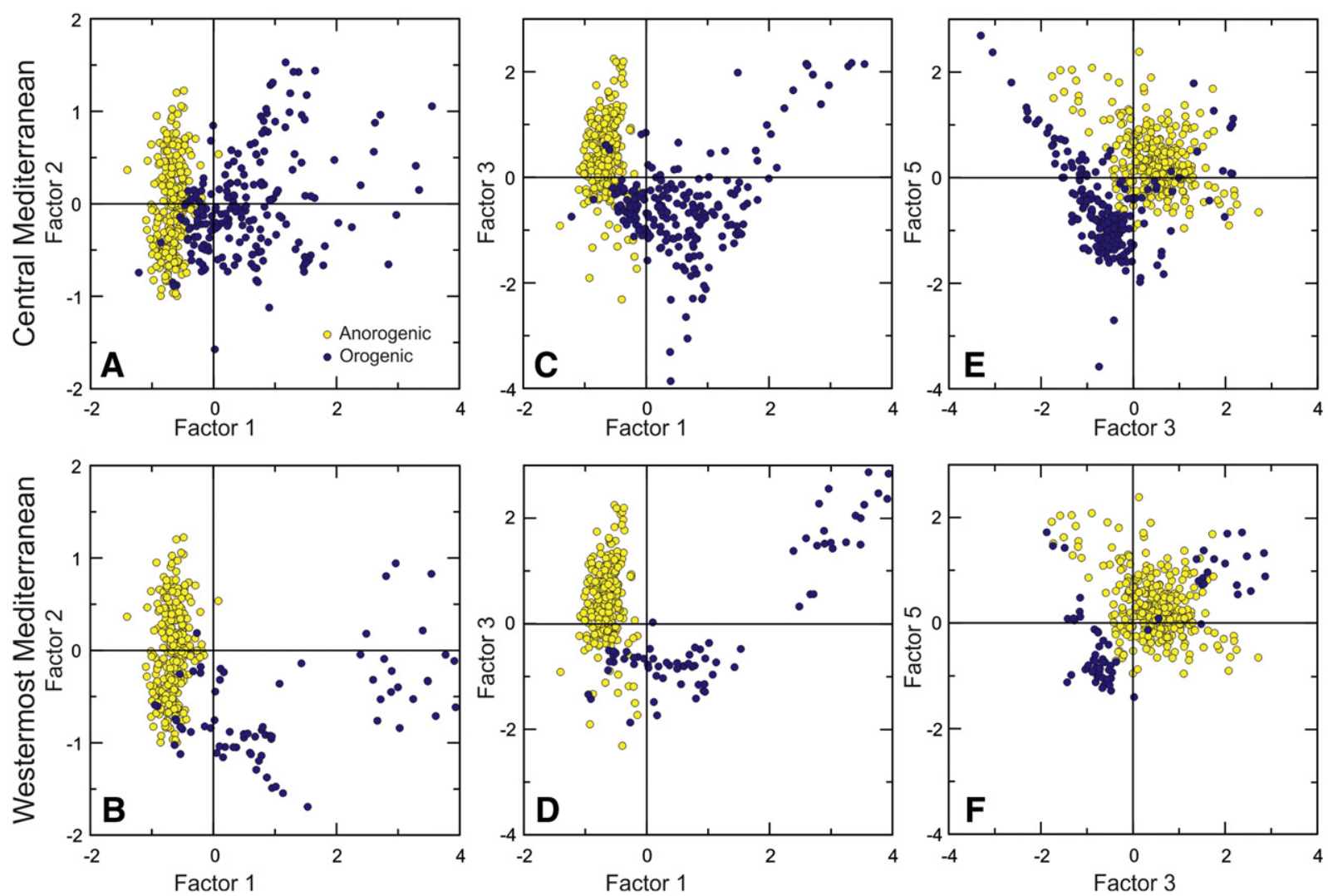

Fig. 4. Orogenic and anorogenic volcanic rocks of Central (A, C and E) and Western (B, D and F) Mediterranean after the statistical analysis. See text for a comprehensive explanation.

volcanism started later ( $8.08-6.37 \mathrm{Ma})$ than the other subductionrelated volcanic activity (14.4 - 6.2 Ma; Duggen et al., 2004, 2005; Turner et al., 1999; and references therein).

Both central and western Mediterranean anorogenic rocks show the same F1 and F2 variations (light blue fields in Fig. 5A and B). The widest compositional range is observed in the Upper Cretaceous rocks of Portugal; all the others fall on the negative side of F1. The major variation for these rocks is observed for Sr, Ba, LREE, MREE and Y contents (i.e., F2) and no age correlation is highlighted.

Fig. 3B, and consequently the values of the factor scores of Fig. 5C and $\mathrm{D}$, give a unique opportunity to observe the variation of all major elements at the same time (except $\mathrm{MnO}$, which is excluded from the factor analysis, and $\mathrm{Na}_{2} \mathrm{O}$, which is included in F5). Subduction-related volcanics mostly plot on the negative side of the y-axis, i.e., they are usually characterised by low $\mathrm{TiO}_{2}, \mathrm{MgO}, \mathrm{P}_{2} \mathrm{O}_{5}$ and high $\mathrm{SiO}_{2}$ and $\mathrm{Al}_{2} \mathrm{O}_{3}$, contents. Lamproites of both central and western Mediterranean areas show high values of F1 and F3, unlike all the other volcanic rocks. The samples from the central and western Mediterranean with intraplate affinity are characterised by a wide $\mathrm{F} 3$ variation, with a group of rocks showing the highest $\mathrm{SiO}_{2}$ and $\mathrm{Al}_{2} \mathrm{O}_{3}$, and lowest $\mathrm{TiO}_{2}, \mathrm{MgO}, \mathrm{P}_{2} \mathrm{O}_{5}$ contents, mostly belonging to Palaeocene German and upper Cretaceous Portuguese suites.

A general tendency observed in Fig. 5E and $\mathrm{F}$ is that, as expected, the orogenic samples are mostly characterised by negative values of F5, i.e., lower $\mathrm{Na}_{2} \mathrm{O}, \mathrm{Zr}$ and $\mathrm{Nb}$ contents than the anorogenic rocks, which generally plot above the zero axes with $\mathrm{Na}_{2} \mathrm{O} / \mathrm{K}_{2} \mathrm{O} \sim 1$. Furthermore, subduction-related rocks of both central and western Mediterranean are aligned along a trend with factors F5 and F3 being inversely correlated. Lamproitic rocks are very well discriminated compared to other samples (light red field in Fig. 5E and F) and are characterised by a positive correlation of factors $\mathrm{F} 3$ and $\mathrm{F} 5$, such that an increase of $\mathrm{Na}_{2} \mathrm{O}, \mathrm{Zr}$ and $\mathrm{Nb}$ is associated with an increase in $\mathrm{TiO}_{2}, \mathrm{MgO}$ and $\mathrm{P}_{2} \mathrm{O}_{5}$, and a decrease of $\mathrm{SiO}_{2}$ and $\mathrm{Al}_{2} \mathrm{O}_{3}$.

\section{Mantle heterogeneities beneath the Mediterranean region}

Volcanic rocks are characterised by geochemical signatures that are typical of the environment in which they are produced. However, processes other than simple partial melting have to be accounted for in order to explain their geochemistry. These processes can be related to metasomatic and refertilisation events in the mantle. Recycling of material via subduction processes can also modify the mantle composition, resulting in variations of the erupted volcanic products. In the central and western Mediterranean, several recycling events of various continental/oceanic subducted domains could have contaminated the lithospheric mantle for millions of years (Fig. 6). These episodes could be as old as Triassic and Permian periods, and be related to the Variscan Orogeny and the subsequent Pangea Triassic rifting processes that predate the central Atlantic opening. Most of the geodynamic models that have been proposed for the central and westernmost Mediterranean (Tyrrhenian area, the Alps, southern Spain, and northern Morocco) invoke upwelling of sublithospheric mantle. This upwelling would be responsible for the erupted anorogenic suites, together with subductionrelated rocks (Duggen et al., 2005; Harangi et al., 2006; Lustrino et al., 2004; Turner et al., 1999) (Fig. 1).

The applied statistical approach permits identification of the major geochemical components through the observation of a considerably smaller number of binary diagrams, obtained by combining major, trace elements and isotopic ratios. In Figs. 4 and 5, orogenic and anorogenic rocks are generally well separated with some overlapping regions, the orogenic samples being characterised by a greater compositional variability that highlights the heterogeneity of their mantle source. When combining F1 and F2, or F1 and F3, various evolutionary trends can be observed that affect the Roman Province, Tuscany or the Western Alps. These trends reflect recycling of material of different origins that was introduced via subduction and caused metasomatism of the pristine mantle that eventually melted. The two end-members 

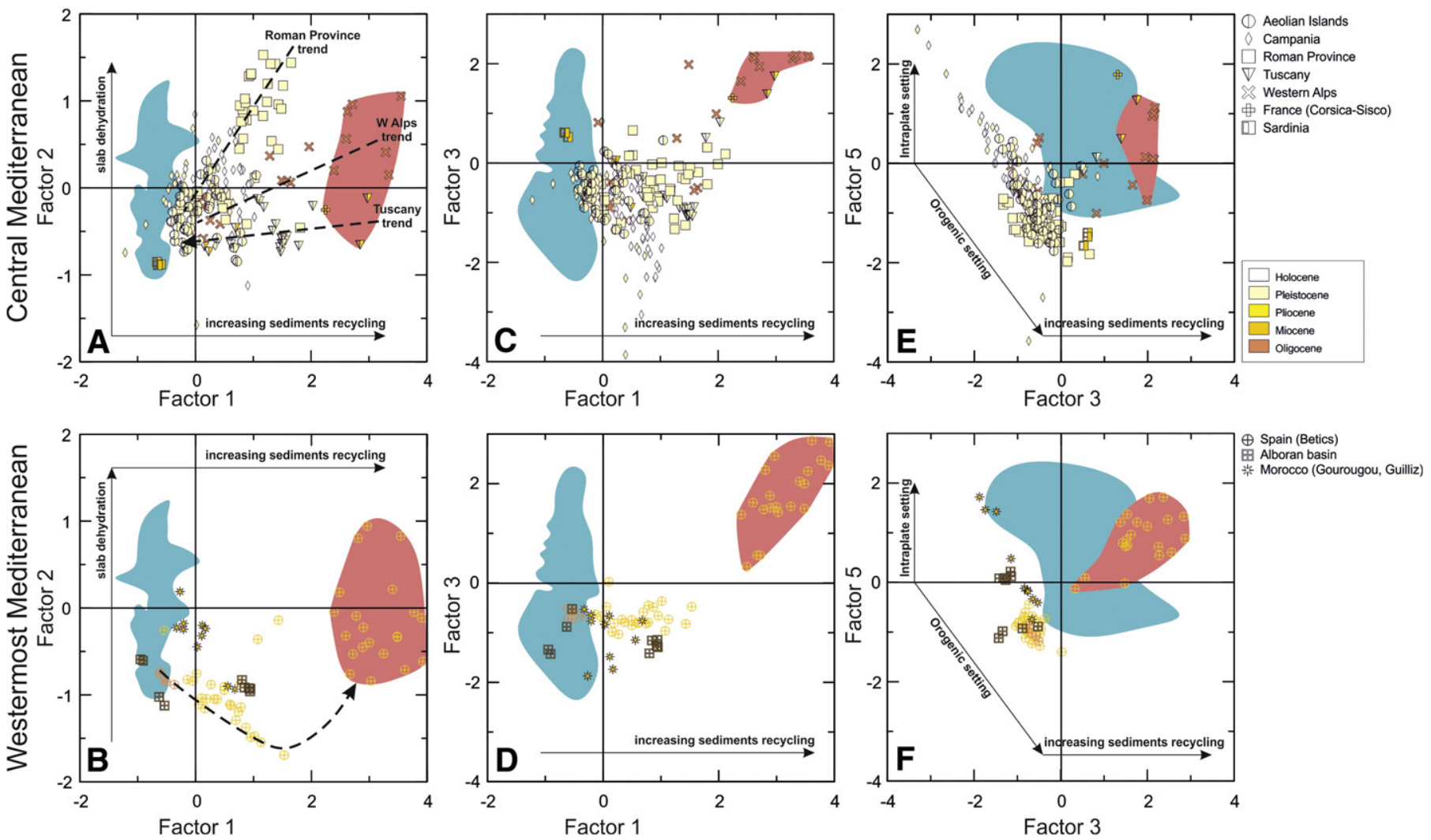

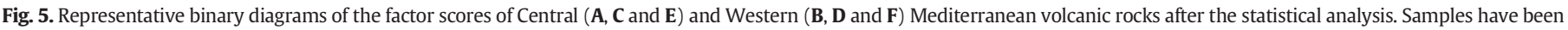

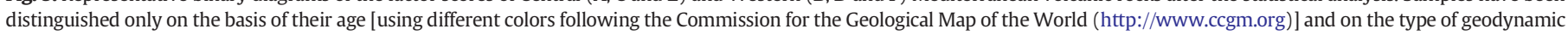

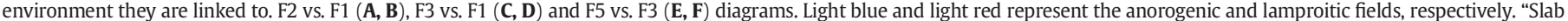

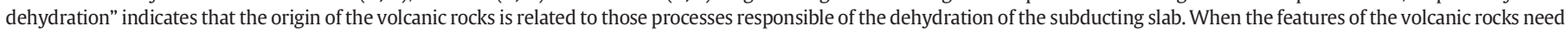

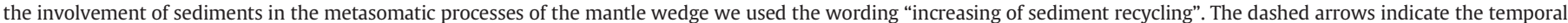

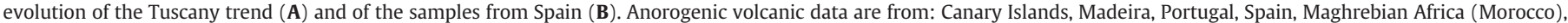

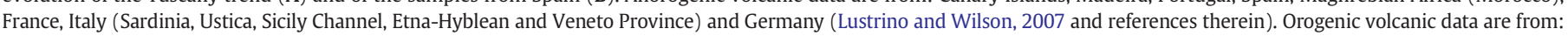

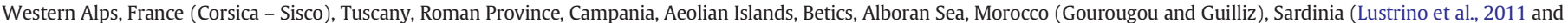
references therein).

represented by the Tuscan and Roman provinces are clearly related to different types of material brought down by the subducting slab, which resulted in different petrographic and geochemical features of the erupted magmas. In the Roman Province, slab-derived melts have metasomatised a fertile mantle, while beneath Tuscany a harzburgitic mantle could have been metasomatised through the subduction of continental crust or sediments (Avanzinelli et al., 2009). Both provinces are characterised by an evolution of their volcanism towards potassic and ultrapotassic end-members. In the Roman Province, the volcanic products evolved from calc-alkaline to HK calc-alkaline and shoshonitic $\mathrm{SiO}_{2}$-saturated (leucite-free), to strongly $\mathrm{SiO}_{2}$-undersaturated leucite tephrites and phonolites (Avanzinelli et al., 2009; Conticelli et al., 2009b; Peccerillo, 2005). The volcanic products from Tuscany evolved to ultrapotassic leucite-free lamproites, characterised by relatively high $\mathrm{MgO}$ and $\mathrm{SiO}_{2}$ with crustal isotopic signature (Conticelli et al., 2009a, and references therein).

The benefits of the statistical approach in geochemical investigations are provided by the discrimination of the orogenic and anorogenic fields, as well as that of the lamproitic rocks. Other evidence in favour of the proposed approach is provided by the combination of the elements within each factor. The positive correlation between $\mathrm{K}_{2} \mathrm{O}$ and $\mathrm{Rb}$ or $\mathrm{U}-\mathrm{Th}-\mathrm{Pb}$, as well as the negative correlation between the ${ }^{87} \mathrm{Sr} /{ }^{86} \mathrm{Sr}$ and ${ }^{143} \mathrm{Nd} /{ }^{144} \mathrm{Nd}$ isotopic ratios on $\mathrm{F} 1$, are clear examples. The negative correlation between $\mathrm{MgO}$ and $\mathrm{SiO}_{2}-\mathrm{Al}_{2} \mathrm{O}_{3}$ recorded also by F3, or the dependence of F4 almost entirely on HREE, further confirm the appropriateness of the approach. Supporting evidence is, finally, also given by F6 and F7 depending on ${ }^{208} \mathrm{~Pb} /{ }^{206} \mathrm{~Pb}-{ }^{207} \mathrm{~Pb} /{ }^{206} \mathrm{~Pb}$, and ${ }^{206} \mathrm{~Pb} /{ }^{204} \mathrm{~Pb}-{ }^{208} \mathrm{~Pb} /{ }^{204} \mathrm{~Pb}$, respectively.

\section{Volcanic activity and the double polarity subduction model}

Geodynamic models that have been proposed for the evolution of the westernmost Mediterranean are mainly based on geologic and seismologic evidence, as well as on petrography and exhumation ages of metamorphic units that compose the inner parts of the Betic-Rif arc. Many of these models are poorly constrained from a volcanological point of view, and volcanic activity is not only used as a key constraint but also as a corollary. The complexity in interpreting the volcanic geochemistry in this region is basically related to the long-term recycling of material, coupled to depletion events caused by partial melting due to subduction or rifting phases (Fig. 6). Modifications of the Mediterranean mantle are, therefore, reflected in the volcanic products, whose geochemical features do not always correspond to the present-day geodynamic environment in which they are sampled (see also Carminati et al., 2012; Lustrino and Wilson, 2007; Lustrino et al., 2011).

Here we analyse the geochemical characteristics of the volcanic rocks in the framework of the recent geodynamic model proposed by Vergés and Fernàndez (2012) for the westernmost Mediterranean area. These authors proposed the existence of two opposite dipping slabs (Fig. 6), which retreated in opposite directions (Fig. 7), based on four key premises related to: 1) the large-scale plate reconstructions addressing the Africa-Iberia plate boundary during the Mesozoic and 
A) 230 Ma Middle Triassic

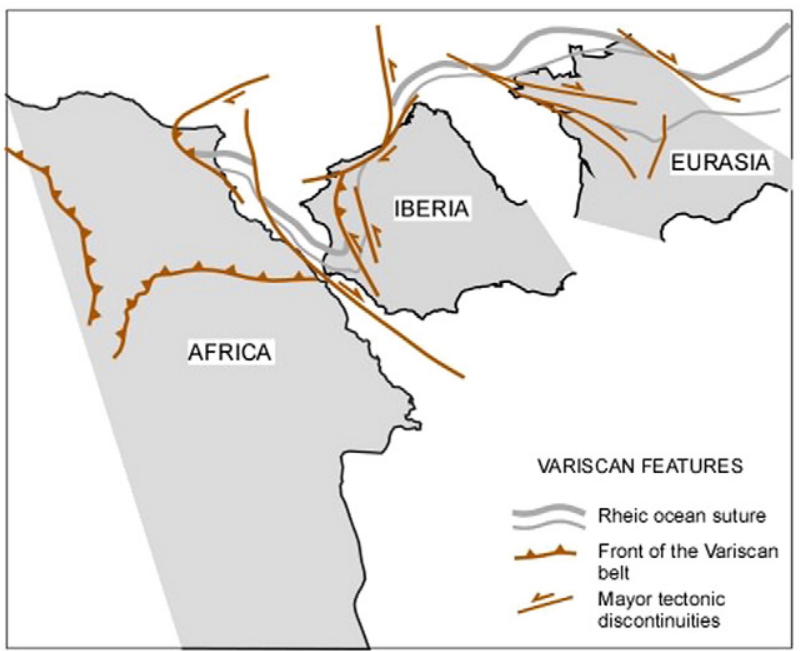

\section{C) $72 \mathrm{Ma}$ (Chron 32) Latest Cretaceous Initial Africa northern convergence}

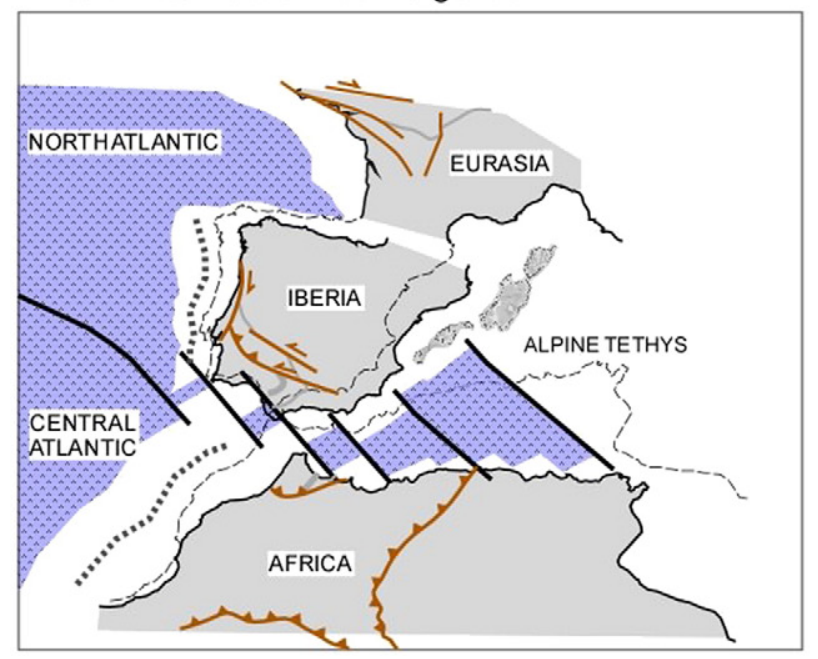

B) $154 \mathrm{Ma}$ (Chron M25) Late Jurassic Central Atlantic - Alpine Tethys transition

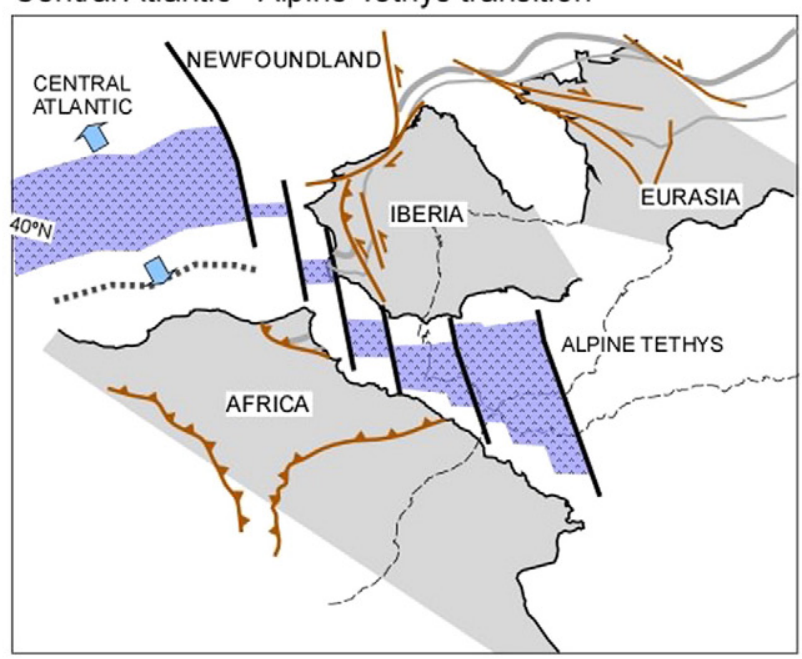

D) $8 \mathrm{Ma}$ (Chron 4) Late Miocene Consumption of Atlantic - Alpine Tethys transition

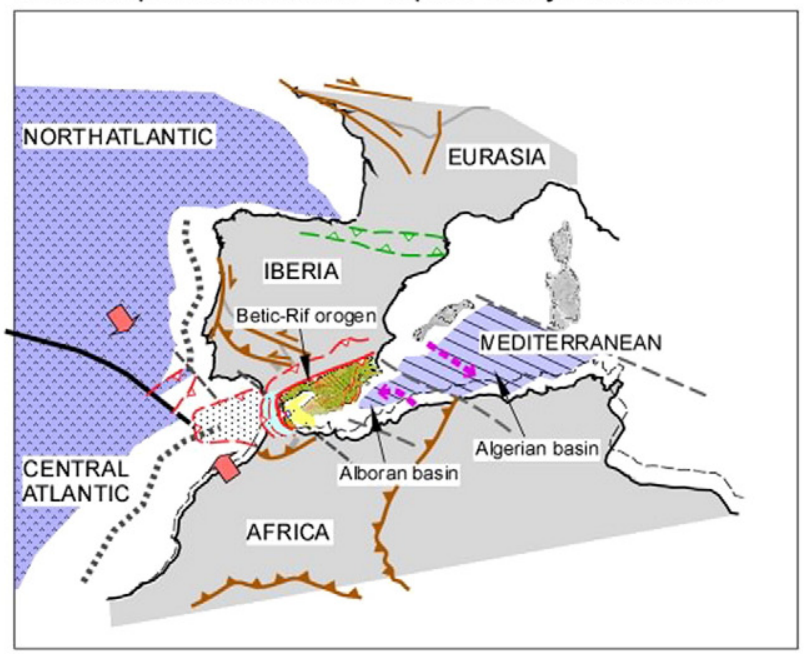

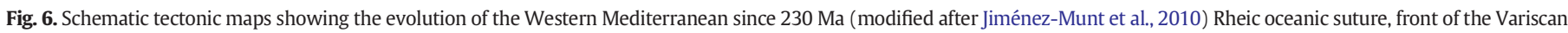

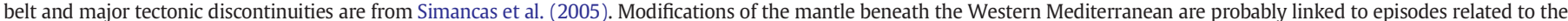

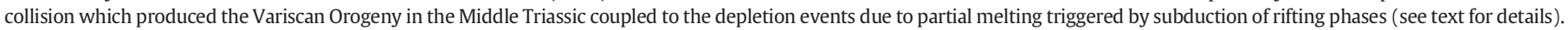

Cenozoic; 2) the geographic distribution of HP/LT metamorphic rocks of the inner orogeny located along the Alboran and Algerian margins; 3 ) the role of mechanical stratigraphy of the Iberia paleo-margin, where the External Units are separated from the Internal Betic-Rif units through Triassic detachment levels; and 4) the timing of onset of compressional deformation along the Betic-Rif system.

This model includes seven time-steps or stages. The first stage was related to the onset of Africa-Iberia convergence at about $85 \mathrm{Ma}$, and volcanic activity was restricted to southwest Iberia far from the Ligurian-Tethys domain. The second stage (middle Eocene, 47-42 Ma) takes into account a HP/LT metamorphic peak (recorded in the Nevado-Filabride complex) related to SE subduction beneath northern Africa. During this stage, no volcanic activity occurred in the westernmost Mediterranean, but some anorogenic volcanic rocks are found in the High Atlas that are probably unrelated to subduction (at Tamazert and Rekkam; Bernard-Griffiths et al., 1991; Bouabdli and Liotard, 1992; Bouabdli et al., 1988; Duggen et al., 2005; Rachdi et al., 1997).

In the third stage (Oligocene, 30-25 Ma), the roll-back phase and exhumation of the HP/LT Ligurian-Tethys metamorphic rocks began. The earliest magmatic manifestation was intrusion of tholeiitic Malaga dykes, dated at 33.6 $\pm 0.6 \mathrm{Ma}$ (Duggen et al., 2004) and 30.2 $\pm 0.9 \mathrm{Ma}$ (Turner et al., 1999). Younger ages ranging from 23 to 17 Ma have been reported by several authors (e.g., Duggen et al., 2004; Torres-Roldán et al., 1986; Turner et al., 1999), coinciding with metamorphic events dated at 22-17 Ma (Kelley and Platt, 1999; Monié et al., 1994; Priem et al., 1979). These young volcanic ages (23-17 Ma) are related to a thermal event that reset the system, rather than being related to magma ascent and dyke emplacement (Duggen et al., 2004; Platt et al., 2013). The tholeiitic Malaga dykes are characterised by moderate Fe-enrichment (Turner et al., 1999). They show crustal contamination, indicated by small negative $\mathrm{Ta}-\mathrm{Nb}, \mathrm{Ti}$ and $\mathrm{Zr}-\mathrm{Hf}$ anomalies, positive $\mathrm{Rb}, \mathrm{U}, \mathrm{K}$ and $\mathrm{Pb}$ anomalies, higher ${ }^{87} \mathrm{Sr} /{ }^{86} \mathrm{Sr}$, and lower ${ }^{143} \mathrm{Nd} /{ }^{144} \mathrm{Nd}$ relative to the depleted mantle, and elevated ${ }^{208} \mathrm{~Pb} /{ }^{204} \mathrm{~Pb}$ and ${ }^{207} \mathrm{~Pb} /{ }^{204} \mathrm{~Pb}$. However, the least contaminated samples show relatively low Fe and high Si contents, flat REE patterns and high HREE concentrations, indicating that partial melting did not take place in the presence of garnet. Turner et al. (1999) calculated 10-15\% of mantle partial melting in the spinel stability field (less than 60-70 km). This allows 


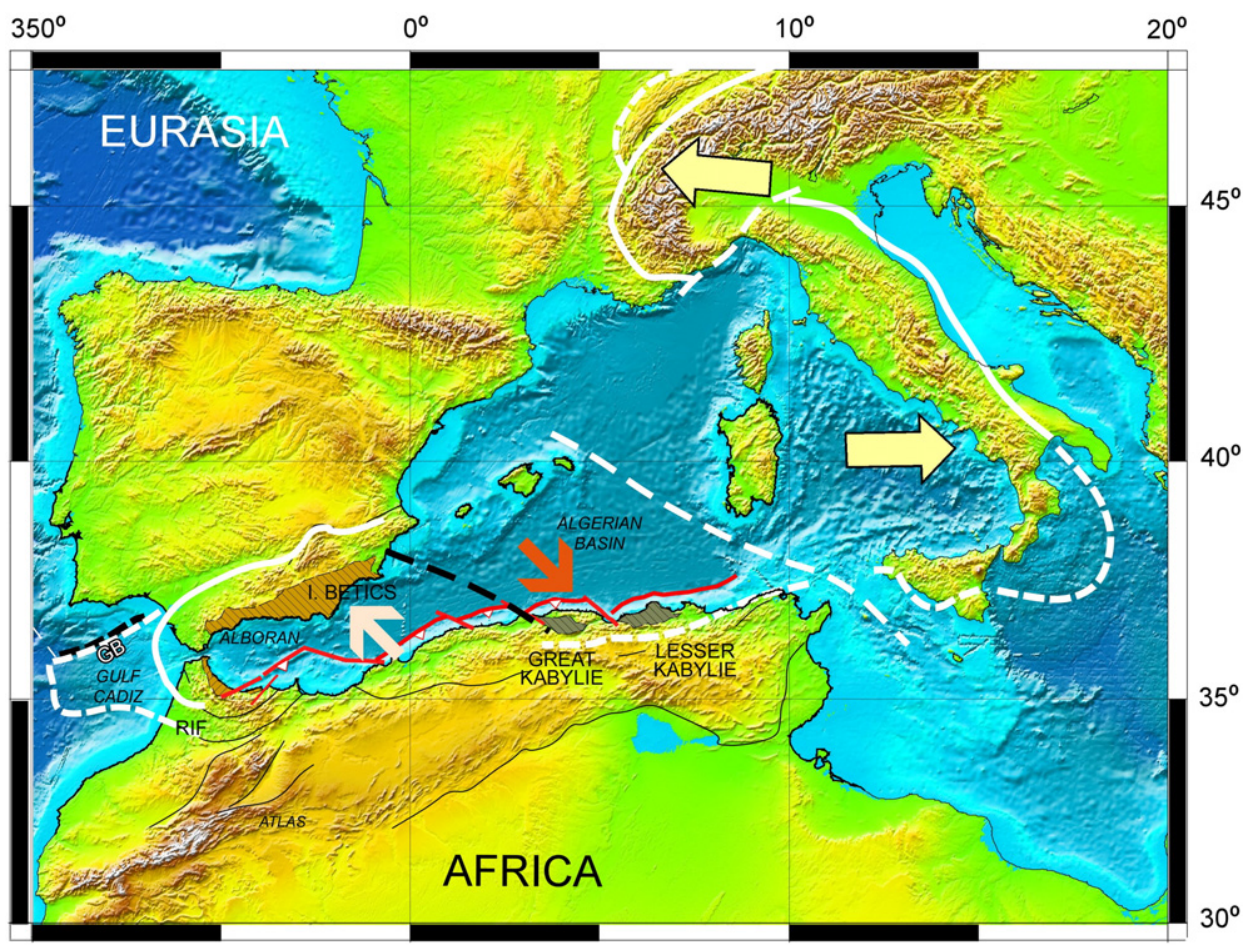

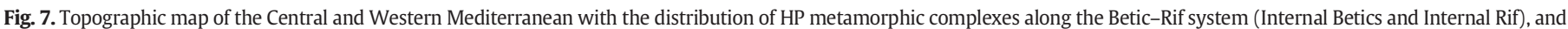

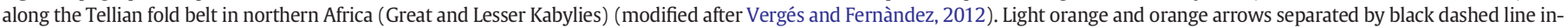

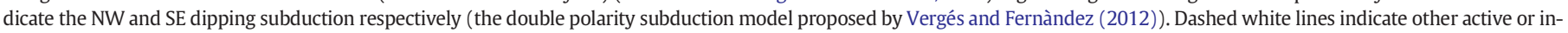
active faults separating the Alps from the Apennines and the Kabylies. GB stands for Guadalquivir Bank.

us to place the genesis of these melts as the results of partial melting of a mantle wedge (Duggen et al., 2004), most probably enriched in incompatible elements through percolation of fluids from the subducting slab and involving a sedimentary component, in agreement with the third stage, described by Vergés and Fernàndez (2012). The Malaguide Complex corresponds to the upper plate and has been tectonically transported to its present position as a consequence of the slab roll-back.

The fourth stage, dated as late Oligocene-early Miocene (27-20 Ma), was characterised by a progressive northwest and westward displacement of the trench resulting in an arcuate subducting slab with a SE to E-dipping polarity and the opening of the Alboran back-arc basin. The absence of volcanic activity is a key feature of this stage, although volcanism sporadically reappeared a few million years later. Cordieritebearing dacite samples in the Mar Menor area have been dated at $18.5 \pm 1.6 \mathrm{Ma}$ (Duggen et al., 2004). These anatectic melts were also reported by Zeck et al. (1999) and are explained as melting of pelitic to quartzo-feldspathic clastic rocks in a slab detachment setting. This hypothesis agrees well with the fifth stage, which was characterised by the end of major extension in the Alboran Basin (18-16 Ma) and the onset of slab tear and E-W extension in the Eastern Betics. The occurrence of some calc-alkaline products in the Alboran Sea (ODP 977 at $\sim 17.6 \mathrm{Ma}$; Duggen et al., 2004) was related to active slab retreat in the West Alboran Basin, as proposed by the model.

Most of the volcanic activity of the western Mediterranean region occurred since $\sim 15-14 \mathrm{Ma}$ [hereinafter, all age datings refer to the data of Duggen et al. (2004) and references therein]. During the Middle to Early Miocene, subduction-related magmas with tholeiitic to HK calcalkaline affinity erupted in different localities: in Ras Tarf (northern Morocco) and Cabo de Gata (southern Spain) at 15 Ma, in the Alboran Sea (ODP 978) around $13 \mathrm{Ma}$, in Oranie (Northern Algeria) and the Yusuf Ridge (Alboran Sea) at $\sim 11 \mathrm{Ma}$, and in the Alboran Ridge at $\sim 10 \mathrm{Ma}$. This volcanism continued between $\sim 9$ and $\sim 7 \mathrm{Ma}$, producing volcanic rocks with a typical subduction signature in the Alboran Sea (tholeiitic/calc-alkaline volcanism at $\sim 9 \mathrm{Ma}$ ) and Northern Algeria (with calc-alkaline affinity, $\sim 9 \mathrm{Ma}$ ). In southern Spain, calc-alkaline magmas erupted at $\sim 8 \mathrm{Ma}$ in Murcia and Mazarron (with sodic alkaline magmas in Picassent; Ancochea and Huertas, 2003). Following stage 6 in Vergés and Fernàndez (2012), this orogenic volcanism is interpreted as a result of partial melting of the mantle wedge related to the W-directed slab roll-back affecting mainly the western part of the Betic-Rif-Alboran system.

The last volcanic phase occurred in the late Miocene-Quaternary and comprised a wide range of volcanic products. The peculiarity of this period was the eruption of sodic alkaline (anorogenic) magmas soon after emplacement of volcanics with typical subduction-related signature. In northern Morocco, calc-alkaline products erupted at $\sim 7$ Ma were followed after only $\sim 1$ My by sodic alkaline magmas. Anorogenic magmas erupted from 3 Ma in northern Algeria (Coulon et al., 2002). Along the Iberian margin, calc-alkaline and HK calc-alkaline magmas were erupted during the late Miocene-Quaternary, especially along the Murcia-Almeria coast. Lamproite-like ultrapotassic magmas (8.08$6.37 \mathrm{Ma}$ ) were erupted in Vera, Cancarix, Fortuna and Jumilla, some of which were emplaced along transform faults (e.g., the Socovos fault, Pérez-Valera et al., 2013). These rocks are usually interpreted as having originated by partial melting of a strongly metasomatised mantle. Sediments played an important role in the generation of lamproite magmas. If the subducting slab was carrying a large quantity of sediments into the mantle, they would strongly metasomatise the mantle wedge by adding incompatible elements $(\mathrm{Ba}, \mathrm{Rb}, \mathrm{Sr}, \mathrm{Th})$ and $\mathrm{K}_{2} \mathrm{O}$, precipitating clinopyroxene, phlogopite and amphibole either as small veins (Foley, 1992) or disseminated in the peridotitic matrix (Coltorti et al., 2004). On the other hand, Bianchini et al. (2015) linked the source of Spanish lamproites to widespread igneous veining (norite veins) observed in composite mantle xenoliths from Tallante, coupled with very refractory peridotite compositions, known from xenolith occurrences in the Iberian margin (Bianchini et al., 2007). According to those authors, the metasomatism has to account for processes related to Cenozoic and 
Paleozoic times. The final magmatic input in southern Spain is represented by the alkaline products of Tallante, erupted between $2.93 \mathrm{Ma}$ and 2.29 Ma (Cebriá et al., 2009).

The Late Miocene-Quaternary volcanic phase in the western Mediterranean area is poorly integrated in the double polarity subduction model. Eruption of calc-alkaline and HK calc-alkaline magmas is in agreement with a mature subduction process (no retreating or active subduction), as proposed by Vergés and Fernàndez (2012) in stage 7. In northern Africa (Morocco and west Algeria), the sodic alkaline volcanic episodes following the typical subduction-related products can be mainly ascribed to three mechanisms: i) sublithospheric flow, as evidenced from mantle anisotropy analysis (Diaz et al., 2010, 2015); ii) slab break-off, as also proposed for the alkaline products of the intra-Apennines volcanism by Bianchini et al. (2008); or iii) splashplume effect (Davies and Bunge, 2006) due to convective instabilities, as has been proposed by Beccaluva et al. (2011) for Sardinia and Calatrava (southern Spain) volcanism. Furthermore, the occurrence of anorogenic rocks in Tallante is additional evidence of a lateral tear responsible of uplift of the eastern part of the Betics (e.g., García-Castellanos and Villaseñor, 2011; Mancilla et al., 2015; Spakman and Wortel, 2004), as included in the model by Vergés and Fernàndez (2012).

\section{Conclusions}

We applied a multi-factor statistical approach to a large and wellstudied geochemical dataset of volcanic rocks in the central and western Mediterranean area with the aim to reproduce the main petrological characteristics that were previously observed with bivariate diagrams. The main advantage of this method is that it allows investigation of the processes that are responsible for the geochemical signature of the studied volcanic rock suites in a fast and simple way. This is possible through statistical determination of the main controlling factors constructed by using the original geochemical elements. The method has the drawback of losing part of the information when extracting the factors, thus limiting a detailed interpretation. However, any methodology has its own advantages and drawbacks, hence factor analysis must be considered as a complementary method to classical bivariate diagrams in order to extract all the information contained in geochemical datasets.

Keeping these considerations in mind, the main concluding remarks from the presented study are:

1. After filtering for common geochemical data, the original datasets that encompassed a total of $\sim 7,000$ orogenic and $\sim 7,800$ anorogenic analyses, were reduced to 283 orogenic and 310 anorogenic volcanic samples.

2. Factor analysis performed using the PCA method reduced the original 36 geochemical parameters, expressed as oxides, elements or isotopic ratios, to seven factors, accounting for $\sim 84 \%$ of the variance.

3. Despite the overlap between anorogenic and orogenic geochemical fields, factor analysis discriminates between these two rock types rather well.

4. Lamproites always plot in a separate field, emphasising the great compositional difference among western and central Mediterranean volcanic rocks, and the huge sediment recycling in the mantle responsible for the origin of these exotic rocks.

5. Factor analysis shows mantle metasomatic processes that are responsible for compositional heterogeneities. The controlling factors are related to mantle wedge percolation of fluids from the subducting slab, and extreme sediment recycling.

6. The double polarity subduction model that has been proposed to explain the evolution of the westernmost Mediterranean area is compatible with the timing and type of volcanic rocks and supported by the controlling processes highlighted by the factor analysis.

7. The close relationships between the tectonic processes responsible for the generation of the erupted magmas in the westernmost
Mediterranean region and their different geochemical signatures are yet to become well established, thus demanding further multidisciplinary efforts.

Supplementary data to this article can be found online at http://dx. doi.org/10.1016/j.lithos.2016.11.018.

\section{Acknowledgements}

The present work has been supported by the research projects WEME (CSIC-201330E111) and MITE (CGL2014-59516-P). We gratefully acknowledge two anonymous reviewers for their constructive comments that greatly improved the first version of the manuscript.

\section{References}

Alvarez, W., Shimabukuro, D.H., 2009. The geological relationships between Sardinia and Calabria during Alpine and Hercynian times. Bollettino della Societa Geologica Italiana 128, 257-268.

Alvarez, W., Cocozza, T., Wezel, F.C., 1974. Fragmentation of the Alpine orogenic belt by microplate dispersal. Nature 248, 309-314.

Ancochea, E., Huertas, M.J., 2003. Nuevos datos geocronológicos y geoquímicos de las manifestaciones volcánicas de Picasent y Cofrentes (Valencia). Geogaceta 32, 31-35.

Araña, V., Aparicio, A., Martin Escorza, C., Garcia Cacho, L., Ortiz, R., Vaquer, R., Barberi, F. Ferrara, G., Albert, J., Gassiot, X., 1983. El volcanismo neogeno-cuaternario de Catalunya: caracteres estructurales, petrologicos y geodinámicos. Acta Geologica Hispánica 18, 1-17.

Avanzinelli, R., Lustrino, M., Mattei, M., Melluso, L., Conticelli, S., 2009. Potassic and ultrapotassic magmatism in the circum-Tyrrhenian region: significance of carbonated pelitic vs. pelitic sediment recycling at destructive plate margins. Lithos 113 , 213-227.

Ayala, C., Torne, M., Pous, J., 2003. The lithosphere-asthenosphere boundary in the Western Mediterranean: Results from 3D gravity and geoid modeling. Earth and Planetary Science Letters 209, 275-290.

Beccaluva, L., Bianchini, G., Bonadiman, C., Siena, F., Vaccaro, C., 2004. Coexisting anorogenic and subduction-related metasomatism in mantle xenoliths from the Betic Cordillera (southern Spain). Lithos 75, 67-87.

Beccaluva, L., Bianchini, G., Mameli, P., Natali, C., 2013. Miocene shoshonite volcanism in Sardinia: Implications for magma sources and geodynamic evolution of the centralwestern Mediterranean. Lithos 180-181, 128-137.

Beccaluva, L., Bianchini, G., Natali, C., Siena, F., 2011. Geodynamic control on orogenic and anorogenic magmatic phases in Sardinia and Southern Spain: inferences for the Cenozoic evolution of the western Mediterranean. Lithos 123, 218-224.

Bernard-Griffiths, J., Fourcade, S., Dupuy, C., 1991. Isotopic study (Sr, Nd, O and C) of lamprophyres and associated dykes from Tamazert (Morroco): crustal contamination processes and source characteristics. Earth and Planetary Science Letters 103, 190-199.

Bezada, M.J., Humphreys, E.D., Toomey, D.R., Harnafi, M., Dávila, J.M., Gallart, J., 2013. Evidence for slab roll-back in westernmost Mediterranean from improved upper mantle imaging. Earth and Planetary Science Letters 368, 51-60.

Bianchini, G., Beccaluva, L., Bonadiman, C., Nowell, G., Pearson, G., Siena, F., Wilson, M. 2007. Evidence of diverse depletion and metasomatic events in harzburgitelherzolite mantle xenoliths from the Iberian plate (Olot, NE Spain): implications for lithosphere accretionary processes. Lithos 94, 25-45.

Bianchini, G., Beccaluva, L., Siena, F., 2008. Subduction-related and intraplate Cenozoic volcanism in the rifted Apennines/Adriatic domain. Lithos 101, 125-140.

Bianchini, G., Braga, R., Langone, A., Natali, C., Tiepolo, M., 2015. Metasedimentary and igneous xenoliths from Tallante (Betic Cordillera, Spain): inferences on crustmantle interactions and clues for post-collisional volcanism magma sources. Lithos 220-223, 191-199.

Bird, P., 1979. Continental delamination and the Colorado Plateau. Journal of Geophysical Research 84, 7561-7571.

Boccaletti, M., Guazzone, G., 1974. Remnant arcs and marginal basins in the Cainozoic development of the Mediterranean. Nature 252, 18-21.

Bonnin, M., Nolet, G., Villaseñor, A., Gallart, J., Thomas, C., 2014. Multiple-frequency tomography of the upper mantle beneath the African/Iberian collision zone. Geophysical Journal International 198, 1458-1473.

Booth-Rea, G., Ranero, C.R., Martínez-Martínez, J.M., Grevemeyer, I., 2007. Crustal types and Tertiary tectonic evolution of the Alborán sea, western Mediterranean. Geochemistry, Geophysics, Geosystems 8, Q10005.

Bouabdli, A., Liotard, J.M., 1992. Kimberlite affinities of the ultrabasic lamprophyres of the Tamazert carbonatite massif, Moroccan High Atlas. Comptes Rendus de l'Academie des Sciences Serie II 314, 351-357.

Bouabdli, A., Dupuy, C., Dostal, J., 1988. Geochemistry of Mesozoic alkaline lamprophyres and related rocks from the Tamazert massif, High Atlas (Morocco). Lithos 22, 43-58.

Carballo, A., Fernandez, M., Torne, M. Jiménez-Munt, I., Villaseñor, A., 2015. Thermal and petrophysical characterization of the lithospheric mantle along the northeastern Iberia geo-transect. Gondwana Research 27, 1430-1445.

Carminati, E., Doglioni, C., 2004. Mediterranean Tectonics, Encyclopedia of Geology. Elsevier, pp. 135-146. 
Carminati, E., Lustrino, M., Doglioni, C., 2012. Geodynamic evolution of the central and western Mediterranean: Tectonics vs. igneous petrology constraints. Tectonophysics 579, 173-192.

Casciello, E., Fernàndez, M., Vergés, J., Cesarano, M., Torne, M., 2015. The Alboran domain in the western Mediterranean evolution: The birth of a concept. Bulletin de la Societe Geologique de France 186, 371-384.

Cebriá, J.M., López-Ruiz, J., 1995. Alkali basalts and leucitites in an extensional intracontinental plate setting: the late Cenozoic Calatrava Volcanic Province (centra Spain). Lithos 35, 27-46

Cebriá, J.M., López-Ruiz, J., Carmona, J., Doblas, M., 2009. Quantitative petrogenetic constraints on the Pliocene alkali basaltic volcanism of the SE Spain Volcanic Province. Journal of Volcanology and Geothermal Research 185, 172-180.

Chiarabba, C., Giacomuzzi, G., Bianchi, I., Agostinetti, N.P., Park, J., 2014. From underplating to delamination-retreat in the northern Apennines. Earth and Planetary Science Letters 403, 108-116.

Coltorti, M., Beccaluva, L., Bonadiman, C., Faccini, B., Ntaflos, T., Siena, F., 2004. Amphibole genesis via metasomatic reaction with clinopyroxene in mantle xenoliths from Victoria Land, Antarctica. Lithos 75, 115-139.

Comas, M.C., García-Dueñas, V., Jurado, M.J., 1992. Neogene tectonic evolution of the Alboran Sea from MCS data. Geo-Marine Letters 12, 157-164.

Comas, M.C., Platt, J.P., Soto, J.I., Watts, A.B., 1999. The origin and tectonic history of the Alboran basin: insights from LEG 161 results. In: Zahn, R., Comas, M.C., Klaus, A. (Eds.), Proceedings of the Ocean Drilling Program, Scientific Results, pp. 555-580.

Conticelli, S., Guarnieri, L., Farinelli, A., Mattei, M., Avanzinelli, R., Bianchini, G., Boari, E. Tommasini, S., Tiepolo, M., Prelević, D., Venturelli, G., 2009a. Trace elements an $\mathrm{Sr}-\mathrm{Nd}-\mathrm{Pb}$ isotopes of $\mathrm{K}$-rich, shoshonitic, and calc-alkaline magmatism of the Western Mediterranean Region: genesis of ultrapotassic to calc-alkaline magmatic associations in a post-collisional geodynamic setting. Lithos 107, 68-92.

Conticelli, S., Marchionni, S., Rosa, D., Giordano, G., Boari, E., Avanzinelli, R., 2009b. Shoshonite and sub-alkaline magmas from an ultrapotassic volcano: $\mathrm{Sr}-\mathrm{Nd}-\mathrm{Pb}$ isotope data on the Roccamonfina volcanic rocks, Roman Magmatic Province, Southern Italy. Contributions to Mineralogy and Petrology 157, 41-63.

Conticelli, S., Melluso, L., Perini, G., Avanzinelli, R., Boari, E., 2004. Petrologic, geochemical and isotopic characteristics of potassic and ultrapotassic magmatism in centralsouthern Italy: inferences on its genesis and on the nature of mantle sources. Periodico di Mineralogia 73, 135-164.

Coulon, C., Megartsi, M.h., Fourcade, S., Maury, R.C., Bellon, H., Louni-Hacini, A., Cotten, J. Coutelle, A., Hermitte, D., 2002. Post-collisional transition from calc-alkaline to alkaline volcanism during the Neogene in Oranie (Algeria): magmatic expression of a slab breakoff. Lithos 62, 87-110.

Dal Piaz, G.V., Bistacchi, A., Massironi, M., 2003. Geological outline of the Alps. Episodes $26,175-180$.

Davies, J.H., Bunge, H.P., 2006. Are splash plumes the origin of minor hotspots? Geology 34, 349-352.

Devoti, R., Riguzzi, F., Cuffaro, M., Doglioni, C., 2008. New GPS constraints on the kinematics of the Apennines subduction. Earth and Planetary Science Letters 273, 163-174.

Dewey, J.F., Helman, M.L., Knott, S.D., Turco, E., Hutton, D.H.W., 1989. Kinematics of the western Mediterranean. Geological Society, London, Special Publications 45, $265-283$.

Díaz, J., Gallart, J., Morais, I., Silveira, G., Pedreira, D., Pulgar, J.A., Dias, N.A., Ruiz, M., González-Cortina, J.M., 2015. From the Bay of Biscay to the High Atlas: completeng the anisotropic characterization of the upper mantle beneath the westernmost Mediterranean region. Tectonophysics 663, 192-202.

Diaz, J., Gallart, J., Villaseñor, A., Mancilla, F., Pazos, A., Córdoba, D., Pulgar, J.A., Ibarra, P., Harnafi, M., 2010. Mantle dynamics beneath the Gibraltar Arc(western Mediterranean) from shear-wave splitting measurementson a dense seismic array. Geophysical Research Letters 37, L18304.

Díaz, J., Pedreira, D., Ruiz, M., Pulgar, J.A., Gallart, J., 2012. Mapping the indentation between the Iberian and Eurasian plates beneath the Western Pyrenees/Eastern Cantabrian Mountains from receiver function analysis. Tectonophysics 570-571, 114-122.

Doblas, M., López-Ruiz, J., Cebriá, J.M., 2007. Cenozoic evolution of the Alboran Domain: a review of the tectonomagmatic models. Special Paper of the Geological Society of America 418, 303-320.

Doglioni, C., Innocenti, F., Morellato, C., Procaccianti, D., Scrocca, D., 2004. On the Tyrrhenian sea opening. Memorie Descrittive della Carta Geologica d'Italia 44 $147-164$

Duggen, S., Hoernle, K., Van Den Bogaard, P., Garbe-Schönberg, D., 2005. Post-collisiona transition from subduction- to intraplate-type magmatism in the westernmost Mediterranean: evidence for continental-edge delamination of subcontinenta lithosphere. Journal of Petrology 46, 1155-1201.

Duggen, S., Hoernle, K., van den Bogaard, P., Harris, C., 2004. Magmatic evolution of the Alboran region: the role of subduction in forming the western Mediterranean and causing the Messinian Salinity Crisis. Earth and Planetary Science Letters 218, 91-108.

El Azzouzi, M., Bellon, H., Coutelle, A., Réhault, J.P., 2014. Miocene magmatism and tectonics within the Peri-Alboran orogen (western Mediterranean). Journal of Geodynamics 77 $171-185$

El Azzouzi, M., Bernard-Griffiths, J., Bellon, H., Maury, R.C., Piqué, A., Fourcade, S., Cotten, J., Hernandez, J., 1999. Évolution des sources du volcanisme marocain au cours du Néogène. Earth and Planetary Science 329, 95-102.

Faccenna, C., Becker, T.W., Auer, L., Billi, A., Boschi, L., Brun, J.P., Capitanio, F.A., Funiciello F., Horvàth, F., Jolivet, L., Piromallo, C., Royden, L., Rossetti, F., Serpelloni, E., 2014. Mantle dynamics in the Mediterranean. Reviews of Geophysics 52, 283-332.

Faccenna, C., Mattei, M., Funiciello, R., Jolivet, L., 1997. Styles of back-arc extension in the Central Mediterranean. Terra Nova 9, 126-130.
Faccenna, C., Piromallo, C., Crespo-Blanc, A., Jolivet, L., Rossetti, F., 2004. Lateral slab deformation and the origin of the western Mediterranean arcs. Tectonics 23, 1-21.

Ferrara, G., Tonarini, S., 1985. Radiometric geochronology in Tuscany: results and problems. Rendiconti della Società Geologica Italiana di Mineralogia e Petrologia 40, 111-124.

Fichtner, A., Villaseñor, A., 2015. Crust and upper mantle of the western Mediterranean Constraints from full-waveform inversion. Earth and Planetary Science Letters 428, $52-62$.

Foley, S., 1992. Vein-plus-wall-rock melting mechanisms in the lithosphere and the origin of potassic alkaline magmas. Lithos $28,435-453$

Frizon de Lamotte, D., Saint Bezar, B., Bracène, R., Mercier, E., 2000. The two main steps of the Atlas building and geodynamics of the western Mediterranean. Tectonics 19, $740-761$.

García-Castellanos, D., Villaseñor, A., 2011. Messinian salinity crisis regulated by competing tectonics and erosion at the Gibraltar arc. Nature 480, 359-363.

García-Dueñas, V., Balanyá, J.C., Martínez-Martínez, J.M., 1992. Miocene extensional detachments in the outcropping basement of the northern Alboran Basin (Betics) and their tectonic implications. Geo-Marine Letters 12, 88-95.

Giacomuzzi, G., Civalleri, M., De Gori, P., Chiarabba, C., 2012. A 3D Vs model of the upper mantle beneath Italy: Insight on the geodynamics of central Mediterranean. Earth and Planetary Science Letters 335-336, 105-120.

Gutscher, M.-A., Malod, J., Rehault, J.-P., Contrucci, I., Klingelhoefer, F., Mendes-Victor, L., Spakman, W., 2002. Evidence for active subduction beneath Gibraltar. Geology 30, 1071-1074.

Harangi, H., Downs, H., Seghedi, I., 2006. Tertiary-Quaternary subduction processes and related magmatism in the Alpine-Mediterranean region. Geological Society Memorier 32, 167-190.

Jiménez-Munt, I., Fernàndez, M., Vergés, J., Afonso, J.C., Garcia-Castellanos, D., Fullea, J., 2010. Lithospheric structure of the Gorringe Bank: insights into its origin and tectonic evolution. Tectonics 29, TC5019.

Jolivet, L., Faccenna, C., 2000. Meditterranean extension and the Africa-Eurasia collision. Tectonics 19, 1095-1106.

Kelley, S.P., Platt, J.P., 1999. Ar-Ar dating of biotite and muscovite from Alboran basement samples, site 976. Proceeding of the Ocean Drilling Program, Scientific Results 161, 301-305.

Lonergan, L., White, N., 1997. Origin of the Betic-Rif mountain belt Tectonics 16, 504-522. Lustrino, M., 2011. What 'anorogenic' igneous rocks can tell us about the chemical composition of the upper mantle: case studies from the circum-Mediterranean area. Geological Magazine 148, 304-316.

Lustrino, M., Wilson, M., 2007. The circum-Mediterranean anorogenic Cenozoic igneous province. Earth-Science Reviews 81, 1-65.

Lustrino, M., Duggen, S., Rosenberg, C.L., 2011. The Central-Western Mediterranean: anomalous igneous activity in an anomalous collisional tectonic setting. EarthScience Reviews 104, 1-40.

Lustrino, M., Morra, V., Melluso, L., Brotzu, P., D'Amelio, F., Fedele, L., Franciosi, L., Lonis, R., Liebercknecht, A.M.P., 2004. The Cenozoic igneous activity of Sardinia. Periodico di Mineralogia 73, 105-134.

Mancilla, F.L., Booth-Rea, G., Stich, D., Pérez-Peña, J.V., Morales, J., Azañón, J.M., Martin, R., Giaconia, F., 2015. Slab rupture and delamination under the Betics and Rif constrained from receiver functions. Tectonophysics 663, 225-237.

Martí, J., Mitjavila, J., Roca, E., Aparicio, A., 1992. Cenozoic magmatism of the Valencia Trough (western Mediterranean): relationship between structural evolution and volcanism. Tectonophysics 203, 145-165.

Mazzoli, S., Helman, M., 1994. Neogene patterns of relative plate motion for AfricaEurope: some implications for recent central Mediterranean tectonics. Geologische Rundschau 83, 464-468

Miller, M.S., Allam, A.A., Becker, T.W., Di Leo, J.F., Wookey, J., 2013. Constraints on the tectonic evolution of the westernmost Mediterranean and northwestern Africa from shear wave splitting analysis. Earth and Planetary Science Letters 375, 234-243.

Monié, P., Torres-Roldán, R.L., García-Casco, A., 1994. Cooling and exhumation of the Western Betic Cordilleras, ${ }^{40} \mathrm{Ar} /{ }^{39} \mathrm{Ar}$ thermochronological constraints on a collapsed terrane. Tectonophysics 238, 353-379.

Palomeras, I., Thurner, S., Levander, A., Liu, K., Villasenor, A., Carbonell, R., Harnafi, M., 2014. Finite-frequency Rayleigh wave tomography of the western Mediterranean: mapping its lithospheric structure. Geochemistry, Geophysics, Geosystems 15, $140-160$

Peccerillo, A., 2005. Plio-Quaternary volcanism in Italy. Springer, Heidelberg, pp. 1-365.

Pérez-Valera, L.A., Rosenbaum, G., Sánchez-Gómez, M., Azor, A., Fernández-Soler, J.M. Pérez-Valera, F., Vasconcelos, P.M., 2013. Age distribution of lamproites along the Socovos Fault (southern Spain) and lithospheric scale tearing. Lithos 180-181, 252-263.

Piromallo, C., Morelli, A., 2003. P wave tomography of the mantle under the AlpineMediterranean area. Journal of Geophysical Research - Solid Earth 108, 1-23.

Platt, J.P., Behr, W.M., Johanesen, K., Williams, J.R., 2013. The Betic-Rif Arc and its orogenic hinterland: a review. Annual Review of Earth and Planetary Sciences 41, 313-357.

Priem, H.N.A., Boelrijk, N.A.I.M., Hebeda, E.H., Oen, I.S., Verdurmen, E.A.T., Verschure, R.H., 1979. Isotopic dating of the emplacement of the ultramafic masses in the Serrania de Ronda, Southern Spain. Contributions to Mineralogy and Petrology 70, 103-109.

Rabinowitz, P.D., LaBrecque, J., 1979. The Mesozoic South Atlantic Ocean and evolution of its continental margins. Journal of Geophysical Research - Solid Earth 84, 5973-6002.

Rachdi, H., Berrahma, M.H. Delaloye, M., Faure-Muret, A, Dahmani, M, 1997. Le volcanisme tertiare du Rekkame (Maroc): pétrologie, géochimie et géochronologie. Journal of African Earth Sciences 24, 259-269.

Reimann, C., Filzmoser, P., Garrett, R.G., 2002. Factor analysis applied to regional geochemical data: problems and possibilities. Applied Geochemistry 17, 185-206. 
Rietveld, T., Van Hout, R., 1993. Statistical techniques for the study of language and language behaviour. Mouton de Gruyter, Berlin.

Roca, E., Frizon de Lamotte, D., Mauffret, A., Bracène, R., Vergés, J., Benaouali, N., Fernàndez, M., Muñoz, J.A., Zeyen, H., 2004. Transect II: Aquitaine Basin - Pyrenees Ebro Basin - Catalan Range - Valencia Trough - Balearic Block - Algerian Basin Kabylies - Atlas - Sahara Platform. In: Cavazza, W., Roure, F., Spakman, W., Stampfli, G.M., Ziegler, P.A. (Eds.), The TRANSMED Atlas. The Mediterranean Region from Crust to Mantle. Springer-Verlag, Berlin. ISBN: 3-540-22181-6, 141 pp.

Rosenbaum, G., Lister, G.S., 2004. Formation of arcuate orogenic belts in the western Mediterranean region. In: Sussman, A.J., Weil, A.B. (Eds.), Orogenic curvature: integrating paleomagnetic and structural analyses: Boulder, Colorado. Geological Society of America Special Paper 383, pp. 41-56.

Rosenbaum, G., Lister, G.S., Duboz, C., 2002a. Reconstruction of the tectonic evolution of the western Mediterranean since the Oligocene. Journal of the Virtual Explorer 8, 107-126.

Rosenbaum, G., Lister, G.S., Duboz, C., 2002b. Relative motions of Africa, Iberia and Europe during Alpine orogeny. Tectonophysics 359, 117-129.

Schettino, A., Turco, E., 2006. Plate kinematics of the western Mediterranean region during the Oligocene and Early Miocene. Geophysical Journal International 166, 1398-1423.

Simancas, J.F., Tahiri, A., Azor, A., Lodeiro, F.G., Martínez Poyatos, D.J., El Hadi, H., 2005. The tectonic frame of the Variscan-Alleghanian orogen in Southern Europe and Northern Africa. Tectonophysics 398, 181-198.

Soto, J.I., Fernández-Ibáñez, F., Fernàndez, M., García-Casco, A., 2008. Thermal structure of the crust in the Gibraltar arc: influence on active tectonics in the western Mediterranean. Geochemistry, Geophysics, Geosystems 9 (Q10011).

Spakman, W., Wortel, R., 2004. A tomographic view on western Mediterranean geodyamics. The TRANSMED Atlas: The Mediterranean Region from Crust to Mantle. pp. 31-52.

Thurner, S., Palomeras, I., Levander, A., Carbonell, R., Lee, C., 2014. Ongoing lithospheric removal in the western Mediterranean: evidence from Ps receiver functions and thermobarometry of Neogene basalts (PICASSO project). Geochemistry, Geophysics, Geosystems 15, 1113-1127.

Torne, M., 1996. Lithospheric structure of the Valencia trough. A brief review. In: Friend, P.F., Dabrio, C.J. (Eds.), Tertiary basins of Spain, the stratigraphic record of crustal kinematics. Cambridge University Press, pp. 49-54 (E2, 400 pp.).
Torne, M., Fernàndez, M., Comas, M.C., Soto, J.I., 2000. Lithospheric structure beneath the Alboran Basin: results from 3D gravity modeling and tectonic relevance. Journal of Geophysical Research - Solid Earth 105, 3209-3228.

Torres-Roldán, R.L., Poli, G., Peccerillo, A., 1986. An Early Miocene arc-tholeiitic magmatic dike event from the Alboran Sea - Evidence for precollisional subduction and backarc crustal extension in the westernmost Mediterranean. Geologische Rundschau 75, 219-234.

Turco, E., Macchiavelli, C., Mazzoli, S., Schettino, A., Pierantoni, P.P., 2012. Kinematic evolution of Alpine Corsica in the framework of Mediterranean mountain belts. Tectonophysics 579, 193-206.

Turner, S.P., Platt, J.P., George, R.M.M., Kelley, S.P., Pearson, D.G., Nowell, G.M., 1999 Magmatism associated with orogenic collapse of the Betic-Alboran Domain, SE Spain. Journal of Petrology 40, 1011-1036.

Van der Voo, R., 1993. Paleomagnetism of the Atlantic Thethys and Iapetus Oceans. Cambridge University Press, Cambridge, United Kingdom, p. 411.

van Hinsbergen, D.J.J., Vissers, R.L.M., Spakman, W., 2014. Origin and consequences of western Mediterranean subduction, roll-back, and slab segmentation. Tectonics 33, 393-419.

Vergés, J., Fernàndez, M., 2012. Tethys-Atlantic interaction along the Iberia-Africa plate boundary: The Betic-Rif orogenic system. Tectonophysics 579, 144-172.

Vergés, J., Sàbat, F., 1999. Constraints on the Neogene Mediterranean kinematic evolution along a $1000 \mathrm{~km}$ transect from Iberia to Africa. Geological Society, London, Special Publications 156, 63-80.

Wilson, M., Bianchini, G., 1999. Tertiary-Quaternary magmatism within the Mediterranean and surrounding regions. Geological Society Special Publication 141-168.

Wortel, R., Govers, R., Spakman, W., 2009. Continental collision and the STEP-wise evolution of convergent plate boundaries: from structure to dynamics. In: Lallemand, S., Funiciello, F. (Eds.), Subduction Zone Geodynamics. Springer, Berlin Heidelberg, pp. 47-59.

Zeck, H.P., Kristensen, A.B., Nakamura, E., 1999. Inherited Palaeozoic and Mesozoic Rb-Sr isotopic signatures in Neogene calc-alkaline volcanics, Alborán Volcanic Province, SE Spain. Journal of Petrology 40, 511-524. 